\title{
Indicatoren onderwijs-arbeidsmarkt technisch en economisch onderwijs (LBO en MBO)
}

Citation for published version (APA):

Wieling, M., de Grip, A., \& van der Velden, R. K. W. (1992). Indicatoren onderwijs-arbeidsmarkt technisch en economisch onderwijs ( $L B O$ en MBO). Researchcentrum voor Onderwijs en Arbeidsmarkt, Faculteit der Economische Wetenschappen. ROA Reports No. 4 https://doi.org/10.26481/umarep.1992004

Document status and date:

Published: 01/01/1992

DOI:

10.26481/umarep.1992004

Document Version:

Publisher's PDF, also known as Version of record

\section{Please check the document version of this publication:}

- A submitted manuscript is the version of the article upon submission and before peer-review. There can be important differences between the submitted version and the official published version of record.

People interested in the research are advised to contact the author for the final version of the publication, or visit the DOI to the publisher's website.

- The final author version and the galley proof are versions of the publication after peer review.

- The final published version features the final layout of the paper including the volume, issue and page numbers.

Link to publication

\footnotetext{
General rights rights.

- You may freely distribute the URL identifying the publication in the public portal. please follow below link for the End User Agreement:

www.umlib.nl/taverne-license

Take down policy

If you believe that this document breaches copyright please contact us at:

repository@maastrichtuniversity.nl

providing details and we will investigate your claim.
}

Copyright and moral rights for the publications made accessible in the public portal are retained by the authors and/or other copyright owners and it is a condition of accessing publications that users recognise and abide by the legal requirements associated with these

- Users may download and print one copy of any publication from the public portal for the purpose of private study or research.

- You may not further distribute the material or use it for any profit-making activity or commercial gain

If the publication is distributed under the terms of Article $25 \mathrm{fa}$ of the Dutch Copyright Act, indicated by the "Taverne" license above, 
ROA-R-1992/4

M.H. Wieling

A. de Grip

R.K.W. van der Velden

RESEARCHCENTRUM VOOR ONDERWIJS EN ARBEIDSMARKT

Faculteit der Economische Wetenschappen

Rijksuniversiteit Limburg

Maastricht, april 1992 
CIP-GEGEVENS KONINKLIJKE BIBLIOTHEEK, DEN HAAG

Wieling, M.H.

Indicatoren onderwijs-arbeidsmarkt technisch en economisch onderwijs (LBO en MBO) /M.H. Wieling, A. de Grip, R.K.W. van der Velden. -Maastricht: Researchcentrum voor Onderwijs en Arbeidsmarkt, Faculteit der Economische Wetenschappen, Rijksuniversiteit Limburg. -(ROA-R1992/4). Met lit. opg. ISBN 90-5321-079-2 geb.

Trefw.: LBO en arbeidsmarkt /MBO en arbeidsmarkt 
INHOUDSOPGAVE

Bladzijde

VERANTWOORDING

1. INLEIDING 1

2. DATA 3

3. WERKLOOSHEID EN WERKZEKERHEID 6

3.1. Werkloosheid 6

3.2. Werkzekerheid 8

4. FUNCTIENIVEAU EN ONDERBENUTTING

4.1. Functieniveau 11

4.2. Onderbenutting 12

5. FLEXIBILITEITSINDICATOREN 16

5.1. Gini-Hirschman coëfficiënt 16

$\begin{array}{ll}\text { 5.2. Beroepenspreiding van opleidingen } & 17\end{array}$

5.3. Branchespreiding van opleidingen 23

6. BESLUIT 26

$\begin{array}{ll}\text { LITERATUUR } & 30\end{array}$

BIJLAGE A: DE GINI-HIRSCHMAN COËFFICIËNT 31

BIJLAGE B: DE BELANGRIJKSTE BEROEPEN PER OPLEIDINGSTYPE 37 


\section{VERANTWOORDING}

Deze studie is uitgevoerd in het kader van de ontwikkeling van het informatiesysteem onderwijs-arbeidsmarkt van het Researchcentrum voor Onderwijs en Arbeidsmarkt (ROA), in opdracht van het Ministerie van Onderwijs en Wetenschappen, het Centraal Bestuur voor de Arbeidsvoorziening en het Landelijk Dienstverlenend Centrum voor studie- en beroepskeuzevoorlichting. Naast prognoses van de toekomstige ontwikkelingen op de arbeidsmarkt, vormt een aantal arbeidsmarktindicatoren ten aanzien van de aansluiting tussen onderwijs en arbeidsmarkt een belangrijk onderdeel van het informatiesysteem.

In De Grip en Heijke (1988) is een eerste aanzet gegeven tot de ontwikkeling van dergelijke arbeidsmarktindicatoren. In De Grip, Van der Velden en Wieling (1991) is voor het Middelbaar Dienstverlenings- en Gezondheidszorgonderwijs (MDGO) nagegaan in hoeverre de data, afkomstig van het grootschalige 'RUBS'-onderzoek onder schoolverlaters, mogelijkheden bieden arbeidsmarktindicatoren te genereren met betrekking tot de aansluiting tussen het gevolgde onderwijs en de (eerste) bestemming op de arbeidsmarkt. In navolging van deze laatstgenoemde studie zal in deze studie een aantal indicatoren worden gekwantificeerd voor het technisch en economisch-administratief onderwijs op LBO- en MBO-niveau. Daarbij ligt de nadruk op het vergelijken van de arbeidsmarktpositie van schoolverlaters met de arbeidsmarktpositie van degenen die al langer op de arbeidsmarkt actief zijn.

Het onderzoek werd uitgevoerd door drs. M.H. Wieling onder begeleiding van dr. A. de Grip en dr. R.K.W. van der Velden. 


\section{INLEIDING}

Naast prognoses van vraag en aanbod op de arbeidsmarkt, spelen arbeidsmarktindicatoren een essentiële rol in het door het Researchcentrum voor Onderwijs en Arbeidsmarkt (ROA) ontwikkelde informatiesysteem (zie ROA, 1992). Deze indicatoren verschaffen enerzijds een indicatie van de latere mogelijkheden op de arbeidsmarkt en de risico's die men daarbij loopt. Anderzijds is er ook behoefte aan arbeidsmarktindicatoren met betrekking tot de huidige arbeidsmarktsituatie. In het algemeen kunnen dergelijke indicatoren een goed beeld geven van de relatie tussen het gevolgde onderwijs en de latere bestemming op de arbeidsmarkt.

In aansluiting op een eerdere studie met betrekking tot het Middelbaar Dienstverlenings- en Gezondheidszorgonderwijs (MDGO) (De Grip, Van der Velden en Wieling, 1991), wordt in dit rapport getracht met behulp van een aantal arbeidsmarktindicatoren een beeld te schetsen van de arbeidsmarktpositie van de technische en economisch-administratieve richtingen van het lager beroepsonderwijs (LBO) en van het middelbaar beroepsonderwijs (MBO). Daarbij wordt niet zoals in de bovengenoemde MDGO-studie, alleen gebruik gemaakt van de resultaten van de RUBS-schoolverlatersenquête (Registratie van Uitstroom en Bestemming van Schoolverlaters), maar wordt de arbeidsmarktpositie van schoolverlaters telkens vergeleken met de arbeidsmarktpositie van de gehele (werkzame) beroepsbevolking met de desbetreffende opleidingsachtergrond. Deze vergelijkingen vinden plaats door de RUBS-gegevens af te zetten tegen de gegevens van de Enquête Beroepsbevolking (EBB) van het Centraal Bureau voor de Statistiek (CBS). Daarnaast wordt gebruik gemaakt van het zogenaamde Informatiesysteem Vraag en Aanbod (ISVA) bestand van de Arbeidsvoorzieningsorganisatie. De gegevens van de RUBSschoolverlatersenquête hebben betrekking op 1989, terwijl de data afkomstig uit de EBB betrekking hebben op het jaar 1990, vanwege het ontbreken van opleidingsgegevens in de EBB van 1989. Dit verschil in waarnemingsjaar zal echter waarschijnlijk slechts tot een geringe vertekening leiden. Wel moet worden opgemerkt dat de onbetrouwbaarheidsmarges van de RUBS-gegevens 1989 groot zijn, gezien de geringe steekproefgrootte ten aanzien van de onderscheiden opleidingstypen en de ongelijke spreiding van het aantal waarnemingen over de regio's. Vanzelfsprekend moet derhalve een belangrijk voorbehoud worden gemaakt bij de interpretatie van de vergelijking van de arbeidsmarktsituatie van de schoolverlaters met die van de gehele beroepsbevolking of werkzame bevolking. Desalniettemin is een dergelijke vergelijking in de meeste gevallen wel terdege indicatief. Afgezien van de hier gepresenteerde resultaten van de vergelijking tussen de arbeidsmarktpositie van schoolverlaters en de werkzame personen in het algemeen, heeft dit rapport vooral ook als doel een eerste indruk te geven van de mogelijkheden die een combinatie van de RUBS-schoolverlatersenquête met de EBB-gegevens in de nabije toekomst zou kunnen bieden.

In dit rapport wordt een soortgelijke opzet gevolgd als in De Grip, Van der Velden en Wieling (1991). Deze opzet is als volgt. Eerst worden in hoofdstuk 2 de gebruikte data-sets besproken. In hoofdstuk 3 staat de kans op werk centraal. Daarbij wordt ingegaan op de werkloosheid onder de beroepsbevolking en onder schoolverlaters en op de conjunctuurgevoeligheid van de werkgelegenheid in de onderscheiden opleidingstypen. Vervolgens wordt in hoofdstuk 4 nader 
ingegaan op het functieniveau van de uitgeoefende beroepen en op de vraag in hoeverre daarbij sprake is van onderbenutting. Daarna komen in hoofdstuk 5 indicatoren aan de orde die betrekking hebben op de mobiliteits- c.q. uitwijkmogelijkheden op de arbeidsmarkt. Tenslotte worden in hoofdstuk 6 de belangrijkste resultaten nogmaals op een rij gezet. 


\section{DATA}

De data die in deze studie worden gebruikt, zijn uit een aantal bronnen afkomstig. Voor gegevens met betrekking tot de kans op werk wordt gebruik gemaakt van het ISVA-bestand. De overige indicatoren worden op basis van de RUBS-schoolverlatersenquête en de EBB berekend. Daarbij worden de indicatoren voor de schoolverlaters gebaseerd op het RUBS-bestand en de indicatoren voor de werkzame personen op de EBB. Zoals in het voorgaande hoofdstuk reeds werd opgemerkt, hebben de RUBS-schoolverlatersgegevens betrekking op het jaar 1989, terwijl de EBB-data betrekking hebben op 1990. Helaas zijn in de EBB 1989 geen opleidingsgegevens op het vereiste aggregatieniveau beschikbaar. Naar verwachting leidt dit verschil in waarnemingsjaar echter slechts tot een geringe vertekening. Dit data-probleem geldt overigens niet voor de te presenteren werkloosheidspercentages. Deze indicator wordt voor beide groepen uitgerekend op basis van het ISVA-bestand 1990.

ISVA-data 1990

Voor het bepalen van de werkloosheidspercentages per opleidingstype zal, zowel voor de beroepsbevolking als voor de schoolverlaters, gebruik worden gemaakt van het ISVA-bestand van de Arbeidsvoorzieningsorganisatie. Dit data-bestand bevat gegevens die afzonderlijke arbeidsbureaus hebben geregistreerd van de bij hen ingeschreven werkzoekenden (het zogenaamde bemiddelingsbestand zonder baan (BZB) van de Arbeidsvoorzieningsorganisatie). Probleem daarbij is wel de zogenaamde 'vervuiling' van dit data-bestand (zie Detmar en Dekker, 1987 en Beekman en De Grip, 1991). Een ander probleem dat zich hierbij voordoet, is dat de door de Arbeidsvoorzieningsorganisatie gehanteerde AROI-Opleidingsindeling niet altijd eenduidig koppelbaar is met de Standaard Onderwijsindeling (SOI) van het CBS. Daar zowel de werkloosheidspercentages voor de gehele beroepsbevolking als de werkloosheidspercentages voor schoolverlaters worden berekend op basis van het ISVA-bestand, wordt de vergelijking van de werkloosheidspercentages van de beroepsbevolking en de schoolverlaters echter niet beïnvloed door de verschillen tussen beide indelingen ${ }^{1}$.

\section{EBB-data 1990}

De berekende arbeidsmarktindicatoren die betrekking hebben op het totaal aantal werkzame personen met een bepaalde opleidingsachtergrond zijn gebaseerd op gegevens uit de EBB van 1990. Dit is het eerste jaar waarvoor opleidingsgegevens uit de EBB beschikbaar zijn. De EBB is een enquête die vanaf 1987 door het CBS onder een steekproef uit de gehele Nederlandse bevolking wordt gehouden. Voor heel Nederland bedraagt de steekproefomvang voor de EBB

1. Dit verschil in coderen van opleidingen in de gehanteerde data-bestanden kan eventueel wel een geringe rol spelen bij het combineren van indicatoren die zijn gebaseerd op AROIcodes met indicatoren die zijn gebaseerd op SOI-codes (zoals bijvoorbeeld de combinatie van werkloosheid enerzijds en de mate van onderbenutting of de flexibiliteitsindicatoren anderzijds). 
1990 ongeveer $1,1 \%$ van de populatie. Ten behoeve van het berekenen van de arbeidsmarktindicatoren wordt gebruik gemaakt van een matrix van de werkzame personen naar beroepsgroep, bedrijfsklasse en opleidingstype. De in de EBB gebruikte codes van beroepsgroepen, bedrijfsklassen en opleidingstypen zijn respectievelijk gebaseerd op de CBSberoepenclassificatie op 3-digitniveau (beroepsgroepen), de Standaard Bedrijfsindeling (SBI) op 2-digitniveau (bedrijfsklassen) en de Standaard Onderwijsindeling (SOI) op 3-digitniveau.

\section{RUBS-data 1989}

De RUBS-enquête is een grootschalige schoolverlatersenquête waarmee een periodieke meting van de uitstroom en bestemming van schoolverlaters uit het voltijd onderwijs wordt beoogd. Het gaat daarbij om een schriftelijke enquête onder schoolverlaters, bijna een jaar na het beëindigen van de opleiding. In het kader van de RUBS-pilotstudie 1989 hebben 11 van de 13 Contactcentra Onderwijs-Arbeid (COA's) in het voorjaar van 1989 een enquête gehouden onder schoolverlaters in het leerjaar 1987/88. Doordat het onderzoek werd gefinancierd vanuit de diverse regionale bronnen, liep de onderzoeksinspanning die de diverse $\mathrm{COA}^{\prime}$ 's konden leveren vaak sterk uiteen, waardoor de aanwezigheid van de verschillende opleidingen in de steekproef per regio aanzienlijke verschillen kan vertonen. Overigens mag worden aangenomen dat de ongelijke regionale spreiding van de RUBS-data, de representativiteit van de hier gepresenteerde arbeidsmarktindicatoren niet al te zeer beïnvloedt ${ }^{2}$.

Over de omvang en samenstelling van de uit de RUBS-data afgeleide populatie kan het volgende worden opgemerkt. Het aantal schoolverlaters dat afkomstig is uit het lager technisch en economisch-administratief onderwijs bedraagt respectievelijk 3456 en 924 . Voor het middelbaar beroepsonderwijs bevatten de RUBS-data voor de technische en economisch-administratieve opleidingstypen respectievelijk 3570 en 2108 schoolverlaters. In de RUBS-enquête worden zowel de gediplomeerde als de voortijdige schoolverlaters meegenomen. Om echter een vergelijking mogelijk te maken tussen de werkzame personen uit de EBB 1990 en de schoolverlaters uit de RUBS-enquête 1989, worden uit het RUBS-bestand de schoolverlaters geselecteerd die in het bezit zijn van het diploma. Bovendien worden ook gediplomeerden die, na de in 1988 voltooide opleiding, een andere dagopleiding zijn gaan volgen tot de schoolverlaters gerekend. De gediplomeerden die in de RUBS-enquête hebben aangegeven dat ze opnieuw een dagopleiding zijn gaan volgen, behoren echter niet tot de potentiële beroepsbevolking en worden derhalve niet in deze studie betrokken. Dit heeft tot gevolg dat voor het lager technisch en economisch-administratief onderwijs respectievelijk 2035 en 355 schoolverlaters worden meegenomen. Voor het middelbaar technisch en economisch-administratief onderwijs bedraagt dit aantal respectievelijk 2100 en 1173 . Om een indicatie te krijgen van de

2. Om na te gaan of de regionale verdeling van respondenten van invloed is op de hier te berekenen indicatoren, is op basis van het enige opleidingstype dat in alle regio's in de RUBS-enquête is meegenomen (MDGO) nagegaan of er voor de te bepalen indicatoren grote verschillen optreden tussen de regio's. De invloed van de regionale verdeling van de schoolverlaters op de te berekenen indicatoren blijkt slechts klein te zijn. Een soortgelijke conclusie wordt getrokken in Berendsen, de Grip, Wieling en Willems (1992). 
betrouwbaarheid van de RUBS-gegevens worden deze aantallen gerelateerd aan de onderwijsstatistieken van het CBS en de onderwijsprognoses en -tellingen van het Ministerie van Onderwijs en Wetenschappen. Hieruit blijkt dat de geselecteerde schoolverlaters uit het lager technisch en economisch-administratief onderwijs respectievelijk $8 \%$ en $9 \%$ vertegenwoordigen van het totaal aantal gediplomeerde schoolverlaters dat in 1988/1989 geen dagopleiding heeft gevolgd. Dit percentage bedraagt voor het middelbaar technisch onderwijs ongeveer $17 \%$, terwijl deze studie ongeveer $10 \%$ van de schoolverlaters uit het middelbaar economischadministratief omvat.

De opleidingen binnen RUBS zijn zodanig gecodeerd dat deze codes direct koppelbaar zijn aan de in de EBB gebruikte SOI-codes. De coderingen van de bedrijfsklassen en beroepsgroepen zijn evenals in de EBB gebaseerd op respectievelijk de CBS-beroepsclassificatie en de SBIbedrijfsclassificatie. De koppelbaarheid van de coderingen in beide bestanden maakt het mogelijk de resultaten van beide enquêtes met elkaar te vergelijken.

Met betrekking tot het middelbaar technisch onderwijs moet overigens worden opgemerkt dat de EBB- en de RUBS-data niet geheel op elkaar aansluiten. In de beschikbare data van de EBB kan bijvoorbeeld geen onderscheid worden gemaakt tussen de voltijd middelbare technische opleiding en de technische opleidingen van het leerlingwezen. In de RUBS-gegevens blijven de schoolverlaters van het leerlingwezen buiten beschouwing. 
$-6-$

\section{WERKLOOSHEID EN WERKZEKERHEID}

\subsection{Werkloosheid}

In dit hoofdstuk staat de kans op werk centraal. In deze paragraaf zal worden ingegaan op de werkloosheid onder de schoolverlaters en de gehele beroepsbevolking met een bepaalde opleidingsachtergrond. Zoals in hoofdstuk 2 reeds werd opgemerkt, zal hier geen gebruik worden gemaakt van de werkloosheidspercentages zoals die uit de RUBS-schoolverlatersenquête kunnen worden vastgesteld, enerzijds omdat de RUBS-data berusten op een kleine steekproef, anderzijds omdat de vervuiling van het ISVA-bestand een vergelijking met gegevens niet afkomstig uit dit data-bestand bemoeilijkt. In plaats daarvan worden de werkloosheidspercentages van schoolverlaters evenals die van de gehele beroepsbevolking berekend op basis van het ISVA-bestand.

Aan dit ISVA-bestand moet een aantal eisen worden opgelegd om de omvang van het zogenaamde Bemiddelingsbestand Zonder Baan (BZB) te bepalen. Om als werkloos te worden geregistreerd, moet aan de volgende eisen worden voldaan:

- men moet blijk geven van de wens om te werken door zich in te schrijven als werkzoekende bij het arbeidsbureau;

- men moet in staat en bereid zijn een betaalde werkkring te aanvaarden en men mag geen (tijdelijke) betaalde baan hebben;

- men moet onmiddellijk beschikbaar zijn om een betaalde baan te aanvaarden;

- de gezochte baan moet een omvang hebben van tenminste 20 uur per week, dat wil zeggen de hoofdactiviteit is gericht op de arbeidsmarkt;

- men moet jonger zijn dan 65 jaar.

Op basis van het BZB-bestand worden de werkloosheidspercentages per opleidingstype berekend, door het aantal werkloze personen met een bepaalde opleidingsachtergrond te relateren aan het aantal werkzame personen plus het aantal werklozen in het betreffende opleidingstype. Vervolgens worden uit het BZB-bestand de werklozen geselecteerd die als schoolverlater staan ingeschreven en tevens korter dan één jaar werkzoekend zijn. Door het aantal werkloze schoolverlaters te relateren aan het totaal aantal schoolverlaters per opleidingstype kan een werkloosheidsindicator voor schoolverlaters worden geconstrueerd (zie ook Beekman en De Grip, 1991). In figuur 1 worden de werkloosheidspercentages voor zowel schoolverlaters als voor de beroepsbevolking weergegeven.

De door Van Paridon (1987) ontwikkelde arbeidsmarktindicator heeft hetzelfde uitgangspunt als de hier berekende werkloosheidsindicator voor de schoolverlaters: het relateren van het aantal werkloze schoolverlaters uit een bepaald opleidingstype gerelateerd aan het totaal aantal schoolverlaters uit het desbetreffende opleidingstype. Door de ongeschoonde werkloosheid voor vervuiling van het werkloosheidsbestand te corrigeren op basis van een veronderstelde hoge vervuilingsgraad van $60 \%$ is door Van Paridon (1987) een indicator geconstrueerd die de actuele schaarste aan schoolverlaters op de arbeidsmarkt moet aangeven. Indien de 
werkloosheid gelijk is aan de frictiewerkloosheid is sprake van een evenwichtige arbeidsmarkt. Uit analyses van het Centraal Planbureau (CPB) blijkt dat de frictiewerkloosheid in Nederland de afgelopen jaren is gestegen. Afhankelijk van de berekeningswijze bedraagt de frictiewerkloosheid tussen de $3,5 \%$ en $5 \%$ (zie CPB, 1988). Het werkloosheidspercentage waarbij de arbeidsmarkt voor het schoolverlaterssegment in evenwicht is, wordt door Van Paridon op basis hiervan op $7 \%$ gesteld, er van uitgaande dat de arbeidsmobiliteit en derhalve ook de frictiewerkloosheid onder jongeren relatief hoog is. In de praktijk blijkt echter dat de meeste mensen vanuit hun huidige baan op zoek gaan naar een andere baan (zie bijvoorbeeld Allaart, Kunnen, Praat, Van Stiphout en Vosse, 1991). De arbeidsmarktmobiliteit komt in dat geval niet tot uitdrukking in het werkloosheidspercentage. Derhalve zullen de werkloosheidspercentages van zowel de beroepsbevolking als van de schoolverlaters in dit rapport worden gerelateerd aan een frictiewerkloosheid van $5 \%$.

Het percentage waarmee Van Paridon corrigeert voor de vervuiling van de werkloosheidsbestanden is tamelijk arbitrair vastgesteld en waarschijnlijk aan de hoge kant. Uit andere studies (zie Detmar en Dekker, 1987) is gebleken dat de hoogte van de vervuiling ongeveer $41 \%$ tot $47 \%$ bedraagt. In deze studie zal daarom worden verondersteld dat de vervuilingsgraad $45 \%$ bedraagt. Daarbij wordt voor de beroepsbevolking en de schoolverlaters dezelfde correctiefactor gehanteerd.

Figuur 1. Werkloosheid per opleidingstype (april 1990)

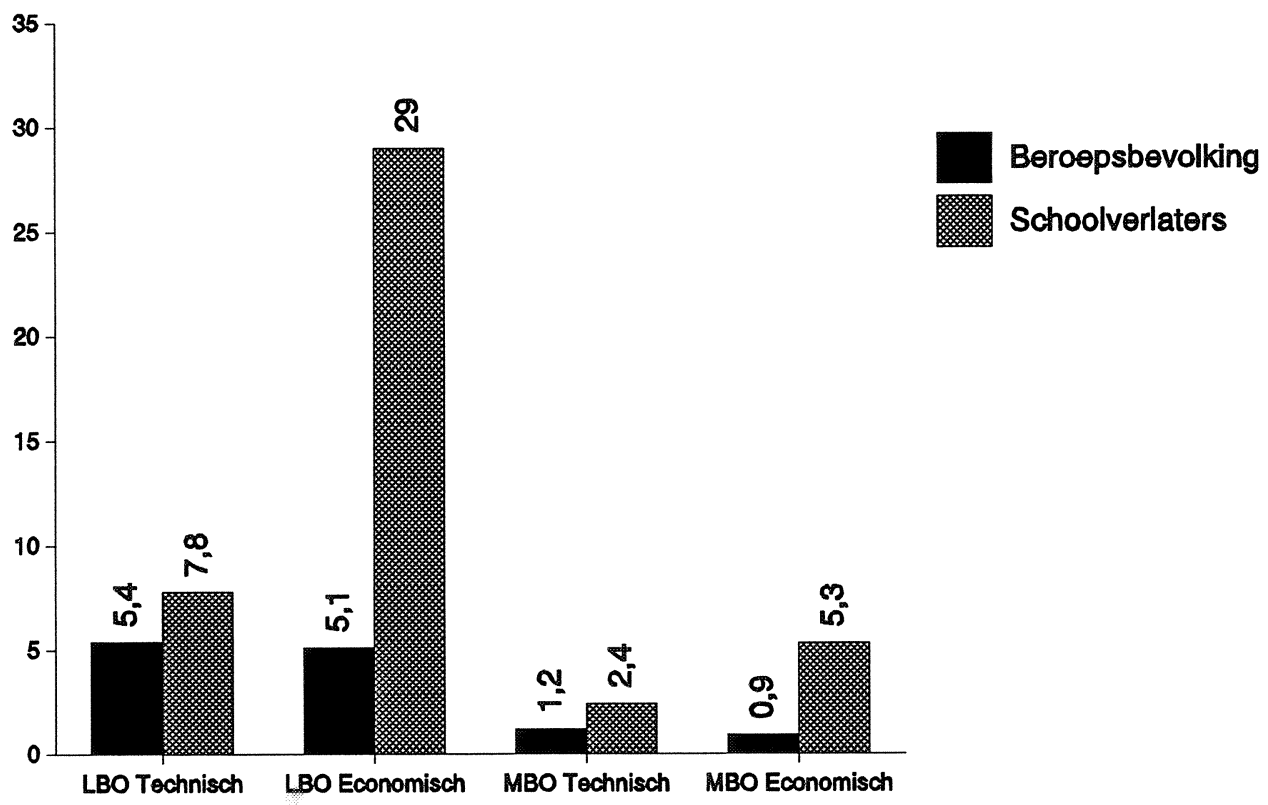

Bron: Arbeidsvoorzieningsorganisatie/ROA 


\section{Lager beroepsonderwijs}

Het werkloosheidspercentage voor zowel schoolverlaters uit het technisch en economischadministratief lager beroepsonderwijs is hoger dan voor de gehele beroepsbevolking. Daarbij is het verschil tussen de schoolverlaters en de beroepsbevolking voor het lager economischadministratief onderwijs groter dan voor het lager technisch onderwijs. Dit grote verschil zou kunnen worden verklaard door een discouraged worker-effect. Aanvankelijk bieden vrijwel alle schoolverlaters zich aan op de arbeidsmarkt, maar mede omdat het vinden van een baan vaak moeilijkheden oplevert, trekken veel personen met deze opleidingsachtergrond zich uiteindelijk terug van de arbeidsmarkt. Voor de beroepsbevolking van het lager technisch en het lager economisch-administratief onderwijs is het werkloosheidspercentage ongeveer gelijk aan de frictiewerkloosheid, hetgeen zou kunnen betekenen dat er min of meer een evenwicht op de arbeidsmarkt bestaat. De werkloosheidspercentages voor de schoolverlaters uit deze beide opleidingstypen zijn groter dan de frictiewerkloosheid, hetgeen zou kunnen wijzen op een overschot op de arbeidsmarkt voor schoolverlaters met deze opleidingsachtergrond.

\section{Middelbaar beroepsonderwijs}

Voor zowel het middelbaar technisch als het middelbaar economisch-administratief onderwijs zijn de werkloosheidspercentages voor schoolverlaters hoger dan de werkloosheidspercentages van de gehele beroepsbevolking met de desbetreffende opleidingsachtergrond. De werkloosheidspercentages betreffende het middelbaar technisch onderwijs blijken voor zowel de beroepsbevolking als voor de schoolverlaters lager te zijn dan de frictiewerkloosheid. Hetzelfde geldt voor de beroepsbevolking afkomstig uit het middelbaar economisch-administratief onderwijs. Slechts voor de schoolverlaters van dit opleidingstype ligt het werkloosheidspercentage rond de frictiewerkloosheid. Voor de beroepsbevolking en de schoolverlaters met een technische of economisch-administratieve opleidingsachtergrond op middelbaar niveau kan op basis van het werkloosheidspercentage gesproken worden van een relatief gunstige positie op de arbeidsmarkt. Dit zou kunnen inhouden dat er een tekort op de arbeidsmarkt bestaat aan technische en economisch-administratieve MBO-ers, met uitzondering van schoolverlaters uit het middelbaar economisch-administratief onderwijs, waarvoor er sprake is van een min of meer evenwichtige situatie op de arbeidsmarkt.

\subsection{Werkzekerheid}

In de vorige paragraaf is op basis van het werkloosheidspercentage een typering van de actuele arbeidsmarktsituatie gegeven. Hierbij is echter buiten beschouwing gebleven of deze arbeidsmarktsituatie van tijdelijke of van meer permanente aard is. In deze paragraaf zal in navolging daarop de conjunctuurgevoeligheid van de werkgelegenheid, ofwel de mate van werkzekerheid, van de afzonderlijke opleidingstypen aan de orde komen. Ook hierbij zal een vergelijking worden gemaakt tussen het totaal aantal werkzame personen en de schoolverlaters.

In de afzonderlijke bedrijfssectoren is de reactie van de werkgelegenheid op conjunctuur- 
$-9-$

schommelingen in het verleden nogal verschillend geweest. Om dit na te gaan is een fluctuatieindex geconstrueerd. Deze index wordt uitgedrukt als het quotiënt van de afwijking van de trendmatige werkgelegenheidsontwikkeling van een bepaalde bedrijfssector in een bepaald jaar en de trendmatige werkgelegenheidsontwikkeling van de desbetreffende bedrijfssector:

$$
F I_{j}=\frac{100}{H} \sum_{i=1}^{H} \frac{\left|F_{j i}\right|}{T_{j t}}
$$

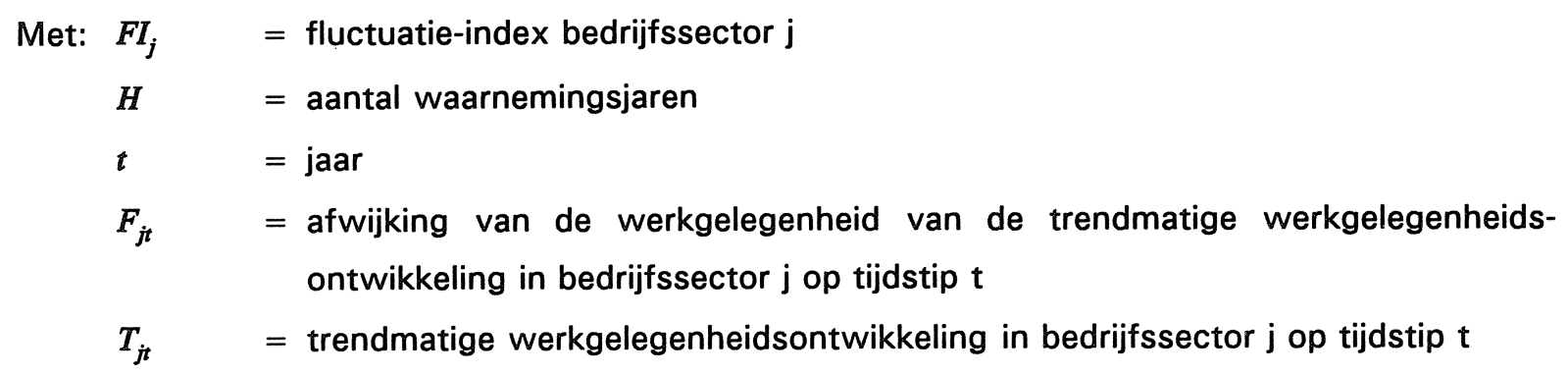

Vervolgens kan uit deze fluctuatie-index van de onderscheiden bedrijfssectoren een fluctuatieindex voor de verschillende opleidingstypen worden afgeleid. Op basis van de veronderstelling dat de werkgelegenheid van de verschillende opleidingstypen binnen een bedrijfssector in gelijke mate fluctueert, wordt de index voor elk opleidingstype bepaald door de indices van de sectoren te wegen met de aandelen van de sectoren in de totale werkgelegenheid van het desbetreffende opleidingstype (zie De Grip en Heijke, 1988):

$$
C G_{k}=\sum_{j=1}^{J} \beta_{k j} F I_{j}
$$

Met: $C G_{k}=$ indicator conjunctuurgevoeligheid opleiding $\mathrm{k}$

$\beta_{k j} \quad=$ aandeel van bedrijfssector $\mathrm{j}$ in totaal aantal werkenden met opleiding $\mathrm{k}$

De conjunctuurindicator is van belang bij het beoordelen van de actuele en/of voorspelde arbeidsmarktpositie van de schoolverlaters in de verschillende opleidingstypen. Bij sterk conjunctuurgevoelige opleidingstypen moet rekening worden gehouden met een meer onzekere werkgelegenheidssituatie.

De fluctuatie-index wordt berekend voor de 21 onderscheiden bedrijfssectoren op basis van de gegevens uit het lange reeksen bestand van het CBS (1950-1988). Vervolgens worden uit deze fluctuatie-indices voor bedrijfssectoren, fluctuatie-indices voor de verschillende opleidingstypen afgeleid, door de indices van de sectoren te wegen met de aandelen van de sectoren in de totale werkgelegenheid van het desbetreffende opleidingstype. Met betrekking tot de werkzame personen wordt daarvoor gebruik gemaakt van de matrix opleidingstype naar bedrijfssector afkomstig uit de EBB 1990. Voor de schoolverlaters wordt de matrix opleiding naar bedrijfssector uit de RUBS-data afgeleid. 
Tabel 1. Conjunctuurindicator per opleidingstype

\begin{tabular}{lcc}
\hline Opleiding & Werkzame personen & Schoolverlaters \\
\hline \multirow{2}{*}{ LBO Technisch } & 2,21 & 2,21 \\
LBO Economisch-administratief & 1,55 & 1,46 \\
MBO Technisch & 2,19 & 1,92 \\
MBO Economisch-administratief & 1,58 & 1,53 \\
\hline
\end{tabular}

Bron: ROA

\section{Lager beroepsonderwijs}

Uit tabel 1 resulteert voor het lager technisch onderwijs zowel bij de schoolverlaters als bij de gehele werkzame bevolking met deze opleidingsachtergrond een relatief grote conjunctuurgevoeligheid van de werkgelegenheid. Met andere woorden, beide worden groepen gekenmerkt door een relatief instabiele werkgelegenheidssituatie. Bij het lager economisch-administratief onderwijs is er sprake van een veel geringere conjunctuurgevoeligheid. Het verschil in de conjunctuurgevoeligheid voor de werkgelegenheid tussen de schoolverlaters en de totale werkzame bevolking is voor deze opleidingstypen niet groot $^{3}$.

\section{Middelbaar beroepsonderwijs}

Het middelbaar technisch onderwijs vertoont evenals het lager technisch onderwijs een relatief grote conjunctuurgevoeligheid. Daarbij valt op dat de conjunctuurgevoeligheid van de werkgelegenheid van de werkzame personen groter is dan dat van de schoolverlaters. Dit verschil wordt veroorzaakt door het feit dat de werkzame personen en de schoolverlaters voor een deel in verschillende bedrijfssectoren werkzaam zijn. Voor het economisch-administratief onderwijs op MBO-niveau wijst de conjunctuurindicator zowel voor de werkzame personen als voor de schoolverlaters op een veel geringere conjunctuurgevoeligheid. De conjunctuurgevoeligheid van de werkgelegenheid voor schoolverlaters is hierbij ongeveer gelijk aan de conjunctuurgevoeligheid voor de werkzame personen met deze opleidingsachtergrond.

3. Overigens wordt hierbij geen uitspraak gedaan over de verschillen in werkzekerheid tussen de beroepsbevolking en de schoolverlaters binnen een bepaalde bedrijfssector. 


\section{FUNCTIENIVEAU EN ONDERBENUTTING}

\subsection{Functieniveau}

In dit hoofdstuk wordt nader ingegaan op indicatoren die iets zeggen over de aard van het werk van de werkende schoolverlaters. Allereerst komt het gemiddelde functieniveau van de beroepen die door de werkzame personen en de schoolverlaters worden uitgeoefend aan de orde. Vervolgens wordt afgeleid in hoeverre er sprake is van onderbenutting van het opleidingsniveau. Daarbij wordt ook het verschil in de mate van onderbenutting van schoolverlaters ten opzichte van de werkzame personen besproken.

Om een eerste indicatie te krijgen van de functieniveaus van de werkzame personen en de schoolverlaters wordt het gemiddelde functieniveau bepaald. De gemiddelde functieniveaus voor beide groepen afkomstig van de vier geselecteerde opleidingstypen worden gepresenteerd in tabel 2. Daarbij wordt gebruik gemaakt van de functieniveaus die door Huijgen (1989) aan de beroepen worden toegekend. Huijgen hanteert een 7-puntsschaal, die het vereiste niveau van kennis en vaardigheden aangeeft. Daarbij heeft niveau 1 betrekking op erg eenvoudig werk en vertegenwoordigt niveau 7 werk van wetenschappelijke aard. Overigens moet worden opgemerkt dat dit gemiddelde functieniveau niets zegt over de spreiding van de werkenden over de verschillende functieniveaus.

Tabel 2. Gemiddeld functieniveau per opleidingstype

\begin{tabular}{lcc}
\hline Opleiding & Werkzame personen & Schoolverlaters \\
\hline LBO Technisch & 3,03 & 3,14 \\
LBO Economisch-administratief & 2,95 & 2,47 \\
MBO Technisch & & 3,52 \\
MBO Economisch-administratief & 3,85 & 3,24 \\
\hline
\end{tabular}

Bron: ROA

\section{Lager beroepsonderwijs}

Tabel 2 laat zien dat het gemiddelde functieniveau voor schoolverlaters van het economischadministratief onderwijs op LBO-niveau aanmerkelijk lager is dan het gemiddelde functieniveau voor de werkzame personen met de desbetreffende opleidingsachtergrond. Tegen de verwachting in, laat de tabel echter zien dat het gemiddelde functieniveau van schoolverlaters uit het lager technisch onderwijs hoger is dan voor alle werkzame personen uit dit opleidingstype. Een mogelijke verklaring hiervoor zou kunnen zijn dat er bij dit opleidingstype nogal eens scholingsveroudering optreedt. Juist in beroepen die in sterke mate de gevolgen ondervinden van technologische ontwikkelingen, kunnen de kwalificaties waarover werkenden beschikken immers snel verouderen en nieuwe kwalificaties worden vereist (Van Hoof en Dronkers, 1980). 
Met name de laag geschoolde oudere werknemers kunnen vaak onvoldoende inspelen op de veranderingen in de vereiste kwalificaties als gevolg van de te geringe breedte van hun initiële opleiding. Indien men, mede daardoor, niet de kans heeft gehad zich bij te scholen zal men mogelijk in beroepen met een lager functieniveau terecht komen. Een andere verklaring voor het relatief hogere functieniveau van de schoolverlaters ten opzichte van de werkzame personen met dit opleidingstype kan worden gezocht in het feit dat de beroepen die worden uitgeoefend door mensen met een lagere technische opleiding veelal een fysiek zware inspanning vereisen. Op latere leeftijd kunnen werknemers deze inspanning echter vaak niet meer opbrengen, waardoor ze van beroep moeten veranderen. Mogelijk komen de desbetreffende werknemers terecht in beroepen met lagere functieniveaus.

\section{Middelbaar beroepsonderwijs}

Met betrekking tot de onderscheiden opleidingstypen op MBO-niveau kan worden opgemerkt, dat zowel voor schoolverlaters uit het middelbaar technisch onderwijs als voor schoolverlaters uit het middelbaar economisch-administratief onderwijs het gemiddelde functieniveau duidelijk lager is dan voor alle werkzame personen in de betreffende opleidingstypen. Daarbij valt wel op dat het verschil in gemiddelde functieniveaus tussen de werkzame personen en de schoolverlaters uit het economisch-administratief onderwijs aanmerkelijk groter is dan voor het technisch onderwijs. Dit wordt waarschijnlijk veroorzaakt door het relatief lagere functieniveau van de intredebanen voor schoolverlaters van het middelbaar economisch-administratief onderwijs. Daarmee wordt al een indicatie gegeven van de aard van de arbeidsmarktsegmenten waarop men terecht komt. Bij degenen met een opleidingsachtergrond MBO techniek wijst het geringe verschil tussen het functieniveau van de schoolverlaters en dat van het totaal aantal werkenden, in de richting van een vakdeelmarkt, met geringere mogelijkheden voor opwaartse mobiliteit. De economisch-administratief opgeleiden starten daarentegen 'lager', maar hebben wel een langer carrièrepad voor zich. Onduidelijk is hier echter of deze opwaartse mobiliteit op de interne of op de externe arbeidsmarkt plaatsvindt.

\subsection{Onderbenutting}

Naast dit gemiddelde functieniveau per opleidingstype is het interessant om te kijken of de baan van de werkzame personen en de schoolverlaters qua functieniveau aansluit op het niveau van de gevolgde opleiding. Daartoe wordt nagegaan hoe groot de mate van onderbenutting is voor de werkzame personen en de schoolverlaters van de vier geselecteerde opleidingstypen. Er is, volgens Huijgen (1989), sprake van onderbenutting indien het functieniveau van de baan lager is dan het niveau van de gevolgde opleiding. Voor het lager beroepsonderwijs is sprake van onderbenutting indien men werkzaam is op de functieniveaus 1 en 2. De functieniveaus 1, 2 en 3 impliceren onderbenutting voor degenen die een opleiding in het middelbaar beroepsonderwijs hebben afgerond. In figuur 2 worden de percentages onderbenutting per onderscheiden opleidingstype gepresenteerd aan de hand van de functies die door de betreffende groepen worden uitgeoefend. 
Figuur 2. Percentage onderbenutting per opleidingstype

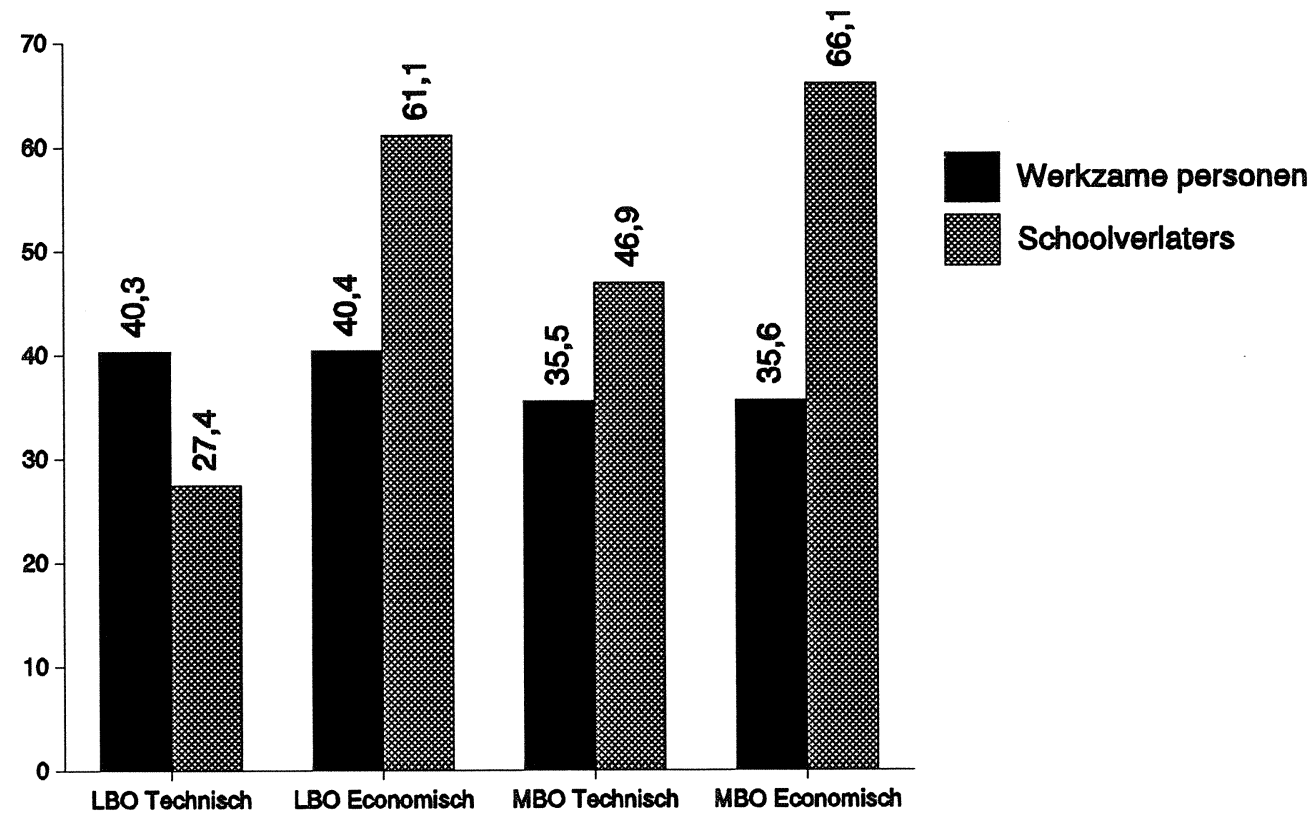

Bron: ROA

\section{Lager beroepsonderwijs}

Voor de totale werkzame bevolking bedraagt het percentage onderbenutting over alle opleidingstypen gemiddeld $30 \%{ }^{4}$. Dit houdt in dat de mate van onderbenutting voor de werkzame personen van het lager technisch en economisch-administratief onderwijs hoger is dan gemiddeld. Hetzelfde geldt voor de schoolverlaters uit het lager economisch-administratief onderwijs. De mate van onderbenutting voor schoolverlaters uit het lager technisch onderwijs is opvallenderwijs lager dan gemiddeld, hetgeen overigens correspondeert met het in voorgaande paragraaf geconstateerde relatief hoge gemiddelde functieniveau van deze schoolverlaters. Bij het lager economisch-administratief onderwijs is het percentage onderbenutting voor schoolverlaters groter dan het percentage onderbenutting voor de hele werkzame bevolking. Het percentage onderbenutting voor de schoolverlaters met deze opleidingsachtergrond ligt derhalve veel hoger dan bij de schoolverlaters van het lager technisch onderwijs.

\section{Middelbaar beroepsonderwijs}

Met betrekking tot de onderscheiden opleidingstypen op middelbaar niveau kan worden opgemerkt, dat zowel voor schoolverlaters uit het middelbaar technisch onderwijs als voor

4. Dit gemiddelde percentage onderbenutting wordt bepaald door het (ongewogen) gemiddelde te berekenen van de percentages onderbenutting voor alle opleidingstypen (zie ook ROA, 1992). 
schoolverlaters uit het middelbaar economisch-administratief onderwijs het percentage onderbenutting aanmerkelijk hoger is dan voor alle werkzame personen in de desbetreffende opleidingstypen. Daarbij valt wel op dat het verschil in percentage onderbenutting tussen de werkzame personen en de schoolverlaters uit het economisch-administratief onderwijs veel groter is dan bij het technisch onderwijs. De relatief hoge onderbenutting van de schoolverlaters is in overeenstemming met de constatering in De Grip, Groot, Heijke en Willems (1990), dat jongeren vaak een tijdelijke onderbenutting accepteren in het vooruitzicht later binnen de interne arbeidsmarkt waarin zij terecht zijn gekomen, door te stromen naar een hoger gekwalificeerde functie. Overigens is de mate van onderbenutting voor de werkzame personen en voor de schoolverlaters voor beide onderscheiden opleidingstypen op middelbaar niveau groter dan gemiddeld. Tenslotte valt ook hier op dat de mate van onderbenutting voor schoolverlaters uit het economisch-administratief onderwijs groter is dan voor schoolverlaters uit het technisch onderwijs.

\section{Onderbenutting en werkloosheid}

In figuur 3 worden de werkloosheidspercentages uitgezet tegen de percentages onderbenutting voor de (werkzame) beroepsbevolking en voor schoolverlaters van de geselecteerde opleidingstypen. Gezamenlijk geven deze indicatoren een beeld van de actuele aans/uitingsproblematiek op de arbeidsmarkt, zowel in kwantitatief als in kwalitatief opzicht. Een complicatie is dat beide indicatoren op twee, tegengestelde, manieren kunnen samenhangen. Ten eerste, kan een hoog percentage onderbenutting er op wijzen dat veel personen zijn uitgeweken naar beroepen met een lager functieniveau, als gevolg waarvan de werkloosheid laag zal zijn. De samenhang tussen de twee indicatoren zal in dit geval negatief zijn. Daartegenover kan echter een andere redenering worden gezet. Een hoge werkloosheid in een bepaald opleidingstype geeft aanleiding tot meer onderbenutting, omdat schoolverlaters die op hun eigen functieniveau geen baan kunnen krijgen, naar beroepen met lagere functieniveaus uitwijken. In dit geval is er sprake van een positieve samenhang tussen de indicatoren.

Op basis van een combinatie van de werkloosheidspercentages en de percentages onderbenutting kan een meer algemene uitspraak worden gedaan over de actuele aansluiting van de (werkzame) beroepsbevolking en de schoolverlaters op de arbeidsmarkt. Figuur 3 wordt daarvoor in vier vlakken verdeeld. De verticale lijn geeft het in deze studie gehanteerde percentage voor de frictiewerkloosheid weer $(5 \%)$. De horizontale lijn geeft het gemiddelde percentage onderbenutting weer $(30 \%)$, gebaseerd op alle werkzame personen over alle opleidingstypen, zoals wordt gemeten op basis van de EBB 1990.

$\mathrm{Er}$ is sprake van een slechte aansluiting, indien het werkloosheidspercentage hoog is en de mate van onderbenutting eveneens (vlak 2). In dit geval is namelijk de kans op werk gering en als men werk heeft, is dit vaak op een relatief laag niveau. Uit figuur 3 kan worden geconcludeerd dat de actuele aansluiting tussen onderwijs en arbeidsmarkt voor schoolverlaters uit het lager economisch-administratief onderwijs slecht is. De schoolverlaters van het economischadministratief onderwijs op middelbaar niveau worden ook gekenmerkt door een hoge mate van 
onderbenutting. De werkloosheid ligt voor dit opleidingstype echter slechts weinig boven de frictiewerkloosheid van $5 \%$. Met betrekking tot mensen die al langere tijd op de arbeidsmarkt werkzaam zijn valt op dat de opleidingen in het lager technisch of economisch-administratief onderwijs weliswaar in vlak 2 liggen, maar dat de afwijkingen van de frictiewerkloosheid niet zo groot is.

Figuur 3. Relatie tussen het werkloosheidspercentage en de mate van onderbenutting

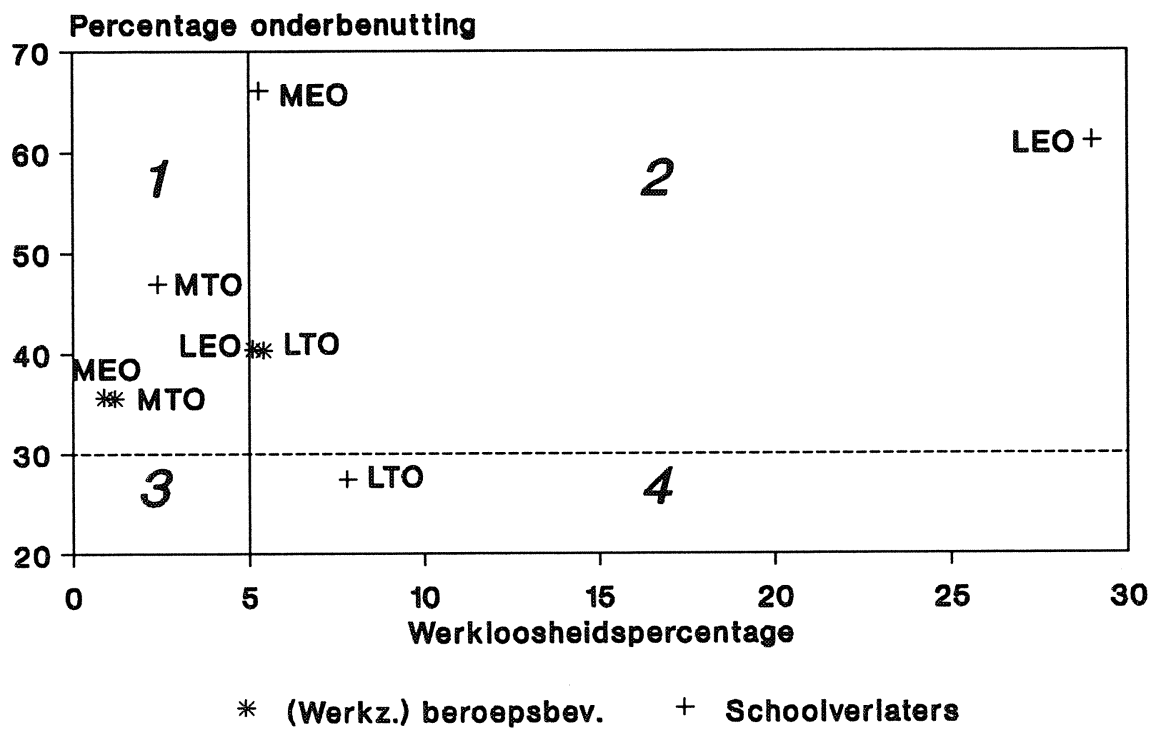

Bron: ROA

LTO = LBO Technisch

LEO = LBO Economisch-administratief

MTO = MBO Technisch

MEO = MBO Economisch-administratief

Bij een geringe werkloosheid en een lage mate van onderbenutting kan daarentegen zonder meer worden gesproken van een goede aansluiting van de opleiding op de arbeidsmarkt (vlak 3). In deze situatie is de kans op werk groot en bovendien betreft het hier werk op een aansluitend niveau. Voor geen van de onderscheiden groepen is dit het geval. Met betrekking tot vlak 1 kan worden opgemerkt dat de kans op werk relatief hoog is, maar dat het niveau van het werk niet goed aansluit op de gevolgde opleiding. Dit geldt voor zowel de schoolverlaters als de (werkzame) beroepsbevolking met een middelbaar technische opleiding en voor de (werkzame) beroepsbevolking uit het middelbaar economisch-administratief onderwijs. Vlak 4 wordt daarentegen gekenmerkt door problemen bij het vinden van werk, maar indien men werk vindt is dit wel op een bij de opleiding aansluitend niveau. Dit zou er op kunnen wijzen dat de uitwijkmogelijkheden naar een lager functieniveau voor schoolverlaters van dit opleidingstype slechts beperkt zijn. Dit beeld geldt voor de schoolverlaters uit het lager technisch onderwijs. 


\section{FLEXIBILITEITSINDICATOREN}

\subsection{Gini-Hirschman coëfficiënt}

In dit hoofdstuk komt de flexibiliteit van de aansluiting tussen onderwijs en arbeidsmarkt aan bod. Om een indicatie hiervan te krijgen wordt een spreidingscoëfficiënt berekend voor zowel de beroepen- als de branchespreiding van opleidingen. Voordat de resultaten worden besproken zal eerst nader worden ingegaan op de spreidingscoëfficiënt die wordt berekend met behulp van de Gini-Hirschman coëfficiënt.

Het zogenaamde naïeve model gaat er van uit dat er een directe en exclusieve relatie bestaat tussen opleidingen en beroepen. Volgens Van Hoof en Dronkers (1980) negeert dit naïeve model van de arbeidsmarkt echter ten onrechte de bestaande flexibiliteit in de aansluiting tussen onderwijs en arbeidsmarkt. Arbeidskrachten met een bepaalde opleiding kunnen in geheel verschillende beroepen terecht komen. Bovendien worden veel beroepen uitgeoefend door mensen met een geheel verschillende opleidingsachtergrond.

Een maatstaf die een indicatie geeft van de bestaande flexibiliteit tussen opleiding enerzijds en beroep en branche anderzijds op de arbeidsmarkt is de Gini-Hirschman coëfficiënt (Sheldon, 1985 en Warnken, 1986). Op basis van deze maatstaf kan de spreiding van de werkzame personen en schoolverlaters met een bepaalde opleidingsachtergrond over de verschillende beroepen en branches worden bepaald. Deze indicator is zeer makkelijk te interpreteren. De indicator kan slechts waarden tussen 0 en 1 aannemen. De spreiding van opleidingen is 0 als het opleidingstype slechts in éen beroep voorkomt en 1 als het opleidingstype gelijkmatig over alle beroepen is verspreid. Hetzelfde geldt voor de branchespreiding van opleidingen. Meestal zal de relatie tussen opleiding en beroep of branche niet worden gekenmerkt door een exclusieve relatie of een situatie van volledige flexibiliteit. De relatie tussen enerzijds beroep of branche en anderzijds opleiding ligt waarschijnlijk tussen deze twee extremen in.

De Gini-Hirschman coëfficiënt heeft de neiging snel te stijgen indien met een bepaalde opleiding meerdere beroepen kunnen worden uitgeoefend. Bovendien wordt de waarde van de spreidingscoëfficiënten hoger naarmate het aggregatieniveau van de beroepen en branches lager is, omdat in dat geval het aantal beroepen en branches waarin de opleidingstypen kunnen voorkomen groter is. De opgenomen correctieterm corrigeert hier in onvoldoende mate voor. In bijlage A zal hier verder op worden ingegaan.

Overigens moet worden bedacht dat louter op basis van de spreidingsindicator geen eenduidige uitspraak over de positie van de schoolverlaters op de arbeidsmarkt kan worden gedaan. De reden hiervoor is dat de hier weergegeven spreidingsindicatoren niet betrekking hebben op de potentiële flexibiliteit, maar op de feitelijk opgetreden flexibiliteit (De Grip en Heijke, 1989). Een lage Gini-Hirschman coëfficiënt betekent bijvoorbeeld niet automatisch dat een schoolverlater uit een bepaald opleidingstype slechts in één of enkele beroep(en) of branche(s) terecht kan komen. Een eenduidige beoordeling van de arbeidsmarktpositie kan pas worden gegeven als de 
spreidingsindicatoren in samenhang met andere indicatoren worden bekeken. In de rest van dit hoofdstuk zullen derhalve de berekende beroepen- en branchespreiding van opleidingstypen in verband worden gebracht met het werkloosheidspercentage per opleidingstype.

\subsection{Beroepenspreiding van opleidingen}

Als eerste wordt de Gini-Hirschman coëfficiënt bepaald om na te gaan of er een exclusieve relatie bestaat tussen een opleiding en een bepaald beroep (naïeve model) of dat er een flexibiliteit in de aansluiting tussen opleidingen en beroepen aanwezig is. Met behulp van flexibiliteitsindicatoren kunnen de uitwijkmogelijkheden die men heeft, wanneer men kiest voor een bepaald opleidingstype, worden aangegeven. Bovendien geven deze indicatoren een indruk van de mate waarin men zich met de keuze van een studie of beroep vastlegt voor een specifieke loopbaan.

De indicator wordt als volgt berekend:

$$
S O B_{k}=\left(1-\sum_{i=1}^{I} \gamma_{k i}^{2}\right) \frac{I}{I-1}
$$

Met: $S O B_{k}=$ Gini-Hirschman coëfficiënt beroepenspreiding van opleiding $\mathrm{k}$

$\gamma_{k i} \quad=$ aandeel van beroep $\mathrm{i}$ in totaal aantal werkenden met opleiding $\mathrm{k}$

$I \quad=$ aantal beroepen

Er wordt bij deze spreidingsindicator uitgegaan van de beroepsgroepenspreiding van opleidingstypen, vanwege het feit dat er ook zal worden ingegaan op een spreidingsmaatstaf waarbij rekening zal worden gehouden met de functieniveaus behorende bij de beroepen die de werkende schoolverlaters uitoefenen. Op beroepsklasseniveau is het niet goed mogelijk functieniveaus toe te kennen. $\mathrm{Er}$ wordt enigszins gecorrigeerd voor het gekozen aggregatieniveau door middel van de correctieterm $\frac{I}{I-1}$.

Tabel 3. Beroepenspreiding per opleidingstype (inclusief beroepen met functieniveaus waarbij sprake is van onderbenutting)

\begin{tabular}{|c|c|c|c|}
\hline LBO & Technisch & 0,98 & $\begin{array}{l}0,95 \\
0,77\end{array}$ \\
\hline LBO & Economisch-administratief & 0,95 & 0,77 \\
\hline MBO & Technisch & 0,99 & 0,94 \\
\hline MBO & Economisch-administratief & 0,97 & 0,6 \\
\hline
\end{tabular}




\section{Lager beroepsonderwijs}

Met betrekking tot het lager beroepsonderwijs blijkt uit tabel 3 dat met name de spreiding van schoolverlaters uit het economisch-administratief onderwijs lager is dan de betreffende spreidingsindicator voor de werkzame personen. Voor het lager technisch onderwijs is het verschil tussen de werkzame personen en de schoolverlaters daarentegen slechts gering. De hoogte van de Gini-Hirschman coëfficiënten kan een gevolg zijn van het relatief hoge aggregatieniveau voor wat betreft de opleidingen. Om hiervan een beeld te krijgen is voor een aantal opleidingsrichtingen uit het lager technisch onderwijs de beroepenspreiding per opleidingsrichting voor de schoolverlaters bepaald (zie tabel A1 van bijlage A). Uit de berekende Gini-Hirschman coëfficiënten (op 3-digitniveau) blijkt dat, met uitzondering van de richting mechanische techniek, de spreidingscoëfficiënten per onderscheiden opleidingsrichting aanmerkelijk lager zijn dan de spreidingscoëfficiënten voor het gehele lager technisch onderwijs. De waarden van deze spreidingscoëfficiënten liggen, met uitzondering van de richtingen installatietechniek $(0,66)$ en mechanische techniek $(0,95)$, tussen de 0,7 en 0,8 , hetgeen overigens nog steeds wijst op een relatief grote beroepenspreiding.

De Gini-Hirschman coëfficiënt geeft alleen weer hoe groot de spreiding van personen uit een bepaald opleidingstype over de verschillende beroepen in het algemeen is. Voor de in deze studie onderscheiden opleidingstypen wordt ook nagegaan in welke beroepsgroepen de werkzame personen en de schoolverlaters feitelijk werkzaam zijn. In bijlage B staan per onderscheiden opleidingstype de beroepsgroepen vermeld waarin meer dan $1 \%$ van de werkzame personen of schoolverlaters werkzaam is ${ }^{5}$.

Voor de schoolverlaters uit het lager technisch onderwijs geldt dat zij, zoals mocht worden verwacht, voornamelijk terecht komen in de technische beroepsgroepen (zie tabel B1 van bijlage B). Daarnaast komen ook een aantal beroepsgroepen in de verzorgende sector voor (beroepsgroepen 'kok en overig keukenpersoneel' en 'kelner, serveerster, barkeeper e.d.'). Dit zijn echter beroepsgroepen die aansluiten op de richtingen koken en serveren van het lager technisch onderwijs. Verder blijkt uit de tabel dat de schoolverlaters, zoals mocht worden verwacht, vrijwel niet in leidinggevende posities voorkomen. Van de werkzame personen met een technische opleidingsachtergrond is een groter deel werkzaam in administratieve beroepsgroepen dan bij de schoolverlaters het geval is. Dit zou een gevolg kunnen zijn van een divergentie-proces, vanwege het feit dat een deel van de werkenden in zijn of haar functie doorgroeit, terwijl een ander deel vanwege de fysiek zware inspanning die veel technische beroepen vereisen, mogelijk terecht komt in administratieve beroepen op een laag functieniveau.

Tabel B2 (zie bijlage B) bevestigt dat de beroepenspreiding van opleidingstypen voor school-

5. Hierbij moet worden opgemerkt dat de beroepsgroepen waarin de werkzame personen met een bepaalde opleidingsachtergrond voorkomen, zijn bepaald op basis van de Arbeidskrachtentelling (AKT) van 1985, vanwege de restricties die het CBS stelt ten aanzien van het publiceren van de EBB-gegevens. 
verlaters uit het lager economisch-administratief onderwijs lager is dan voor de werkzame personen met deze opleidingsachtergrond. Daarnaast blijkt dat de werkzame personen voornamelijk in de administratieve en commerciële richtingen terecht komen, terwijl de schoolverlaters ook in meer vaktechnische beroepen werkzaam zijn.

\section{Middelbaar beroepsonderwijs}

Ook voor het onderwijs op middelbaar niveau geldt dat de beroepenspreiding van schoolverlaters uit het middelbaar economisch-administratieve onderwijs lager is dan de desbetreffende spreidingsindicator voor alle werkzame personen met deze opleidingsachtergrond. In paragraaf 4.1 is reeds gebleken dat de schoolverlaters met een economischadministratieve opleiding op een relatief laag functieniveau werkzaam zijn. Hier blijkt bovendien dat deze groep schoolverlaters in een relatief beperkt aantal intredefuncties terecht komen. Indien de spreidingscoëfficiënten voor de schoolverlaters voor een aantal meer specifieke opleidingsrichtingen worden berekend, blijkt dat de commerciële richting een hogere spreiding heeft dan de andere opleidingsrichtingen binnen het middelbaar economisch-administratief onderwijs (zie tabel A1 van bijlage A). Voor met name de administratieve richting is de spreidingsindicator op 3-digitniveau zelfs lager dan de indicator voor alle schoolverlaters uit het economisch-administratief onderwijs op middelbaar niveau.

In eerste instantie zou men kunnen denken dat de hoge beroepenspreiding er ook bij de technisch opgeleiden op wijst dat men niet werkzaam is op een op de opleiding aansluitende vakdeelmarkt. Een dergelijke conclusie is hier echter voorbarig, omdat wordt uitgegaan van een relatief breed gedefinieerde opleidingscategorie. Dit geldt met name voor het technisch onderwijs waar vaak sprake is van onderling sterk afgebakende vakrichtingen. Derhalve worden voor de schoolverlaters van een aantal opleidingsrichtingen de Gini-Hirschman coëfficiënten berekend (zie tabel A1 van bijlage A). Hieruit blijkt dat de indicatoren van de beroepenspreiding voor de opleidingsrichtingen, met uitzondering van de opleidingsrichting werktuigbouwkunde, aanmerkelijk lager zijn dan voor de schoolverlaters uit het hele middelbaar technisch onderwijs. Er moet echter worden opgemerkt dat de spreidingsindicatoren (op 3-digitniveau) voor de overige opleidingsrichtingen toch nog relatief hoog zijn, hetgeen wijst in de richting van nietspecifieke vakdeelmarkten.

De schoolverlaters en werkzame personen uit het middelbaar technisch onderwijs komen veelal terecht in technische beroepsgroepen. Daarnaast blijkt uit tabel B3 van bijlage B dat de schoolverlaters ook werkzaam zijn in administratieve en commerciële beroepsgroepen. De werkzame personen komen veelvuldiger voor in zogenaamde vakspecialistische functies. Verder blijkt uit de tabel ook dat de schoolverlaters vrijwel niet in de leidinggevende posities voorkomen.

De beroepenspreiding van opleidingstypen is voor schoolverlaters uit het middelbaar economisch-administratief onderwijs lager dan voor de totale groep werkzame personen met deze opleidingsachtergrond, hetgeen duidelijk is terug te vinden in tabel B4 van bijlage B. 
Vrijwel alle beroepen die door schoolverlaters uit dit opleidingstype worden uitgeoefend, worden ook uitgeoefend door de werkzame personen die een economisch-administratieve opleiding op middelbaar niveau hebben gevolgd. Zowel de werkzame personen als de schoolverlaters zijn voornamelijk te vinden in administratieve en commerciële beroepen. Dit zou erop kunnen duiden dat voor de werkenden met deze opleidingsachtergrond sprake is van vrij afgebakende carrièrepaden.

\section{Beroepenspreiding exclusief onderbenutting}

Bovenstaande spreidingscoëfficiënten zijn berekend op basis van alle beroepen die door de werkzame personen en door de schoolverlaters worden uitgeoefend. Daarbij is geen rekening gehouden met het functieniveau van de banen waarnaar men uitwijkt, met andere woorden: de eventuele onderbenutting van de gevolgde opleiding blijft buiten beeld. Het ligt, zoals gezegd, voor de hand dat indien men aanvankelijk geen werk kan vinden dat op de gevolgde opleiding aansluit, men na verloop van tijd geneigd zal zijn een baan te aanvaarden die minder adequaat op de gevolgde opleiding aansluit. De discrepantie die in dat geval ontstaat kan betrekking hebben op de richting en/of op het niveau van het werk.

Indien men voor de verschillende opleidingstypen een uitspraak wil doen over de uitwijkmogelijkheden op de arbeidsmarkt in positieve zin, moeten de functies waarin sprake is van onderbenutting niet worden meegenomen. Bij uitwijkmogelijkheden naar lagere functieniveaus is er namelijk niet sprake van 'echte' alternatieven. Om hiervan een beeld te krijgen wordt de beroepenspreiding van opleidingstypen ook bepaald door alleen te kijken naar beroepen met een functieniveau van 4 of hoger voor degenen met een MBO-opleiding. Voor de LBO-opgeleiden is alleen gekeken naar beroepen met een functieniveau van 3 of hoger ${ }^{6}$.

Tabel 4. Beroepenspreiding per opleidingstype (exclusief beroepen met functieniveaus waarbij sprake is van onderbenutting)

Opleiding Werkzame personen Schoolverlaters

\begin{tabular}{|c|c|c|c|}
\hline LBO & Technisch & 0,97 & 0,92 \\
\hline LBO & Economisch-administratief & 0,91 & 0,80 \\
\hline $\begin{array}{l}\text { MBO } \\
\text { MBO }\end{array}$ & $\begin{array}{l}\text { Technisch } \\
\text { Economisch-administratief }\end{array}$ & $\begin{array}{l}0,97 \\
0,96\end{array}$ & $\begin{array}{l}0,95 \\
0,61\end{array}$ \\
\hline
\end{tabular}

Bron: ROA

6. Bij de beroepenspreiding van opleidingstypen, die de onderbenutting buiten beschouwing laat, is het aantal beroepsgroepen dat wordt meegenomen kleiner dan het totaal door het CBS onderscheiden beroepsgroepen. Hiervoor wordt echter enigszins gecorrigeerd (zie vergelijking 3). 


\section{Lager beroepsonderwijs}

De flexibiliteitsindicator laat voor de technisch en economisch-administratief opgeleiden op LBOniveau een hogere spreiding voor de werkzame personen zien dan voor de schoolverlaters. Daarbij is het verschil tussen schoolverlaters en de werkzame personen uit het lager economisch-administratief onderwijs groter. De oorzaak van dit verschil ligt wellicht in het zoekgedrag van schoolverlaters in de eerste jaren dat deze zich op de arbeidsmarkt aanbieden. Indien met betrekking tot de schoolverlaters enkele opleidingsrichtingen uit het lager technisch onderwijs nader worden bekeken, dan blijkt dat voor de schoolverlaters de spreidingscoëfficiënten op 3-digitniveau, met uitzondering van mechanische techniek, beduidend lager zijn dan voor de schoolverlaters uit het hele technisch onderwijs op LBO-niveau (zie tabel A2 van bijlage A).

\section{Middelbaar beroepsonderwijs}

Voor het onderwijs op middelbaar niveau geldt dat de beroepenspreiding voor de werkzame personen afkomstig uit het technische onderwijs ongeveer hetzelfde is als voor de schoolverlaters. De flexibiliteit tussen opleiding en beroep voor schoolverlaters uit het economisch-administratief onderwijs ligt echter beduidend lager dan bij de totale groep werkzame personen. Indien voor de schoolverlaters binnen het middelbaar technisch en economisch-administratief onderwijs een aantal opleidingsrichtingen worden onderscheiden (zie tabel $A 2$ in bijlage A), dan valt op dat voor de richtingen binnen het middelbaar technisch onderwijs de beroepenspreiding op 3-digitniveau lager is dan voor de totale groep schoolverlaters uit het technisch onderwijs. Slechts de richting werktuigbouwkunde wordt gekenmerkt door een zeer hoge beroepenspreiding. Voor de drie onderscheiden opleidingsrichtingen uit het middelbaar economisch-administratief onderwijs geldt dat voor de schoolverlaters uit de secretariële richting de spreidingscoëfficiënt zeer laag is. Hier blijkt duidelijk sprake te zijn van een specifieke vakdeelmarkt, waarbij er alleen uitwijkmogelijkheden naar beroepen met een lager functieniveau zijn. Voor de administratieve en commerciële richting zijn de spreidingscoëfficiënten ten opzichte van de schoolverlaters uit het hele middelbaar economisch-administratief onderwijs iets lager.

\section{Beroepenspreiding exclusief onderbenutting en werkloosheid}

In figuur 4 worden de landelijke werkloosheidspercentages afgezet tegen de beroepsgroepenspreiding van de opleidingstypen, exclusief de beroepen waarbij er sprake is van onderbenutting. Gezamenlijk geven deze beide indicatoren een beeld van de 'structurele' arbeidsmarktpositie van een opleiding. Zo kan er worden nagegaan hoe succesvol men is in het verwerven van werk en in hoeverre een opleiding zich richt op én specifiek segment van de arbeidsmarkt of dat men met een opleiding in meerdere segmenten terecht kan komen.

Beide indicatoren kunnen overigens op twee, tegengestelde, manieren samenhangen. Ten eerste, kan een hoge spreidingscoëfficiënt wijzen op veel uitwijkmogelijkheden, als gevolg 
waarvan de werkloosheid voor de betreffende opleiding laag zal zijn. De samenhang tussen de twee indicatoren zal in dit geval negatief zijn. Daartegenover kan echter een andere redenering worden gezet. Een hoge werkloosheid in een bepaald opleidingstype geeft aanleiding tot een grotere spreiding, omdat degenen die in hun eigen beroepsdomein geen baan kunnen krijgen, in andere beroepen proberen werk te vinden. In dit geval is er sprake van een positieve samenhang tussen de indicatoren.

Figuur 4. Relatie tussen het werkloosheidspercentage en de beroepenspreiding van de opleidingstypen (exclusief beroepen met functieniveaus waarbij sprake is van onderbenutting)

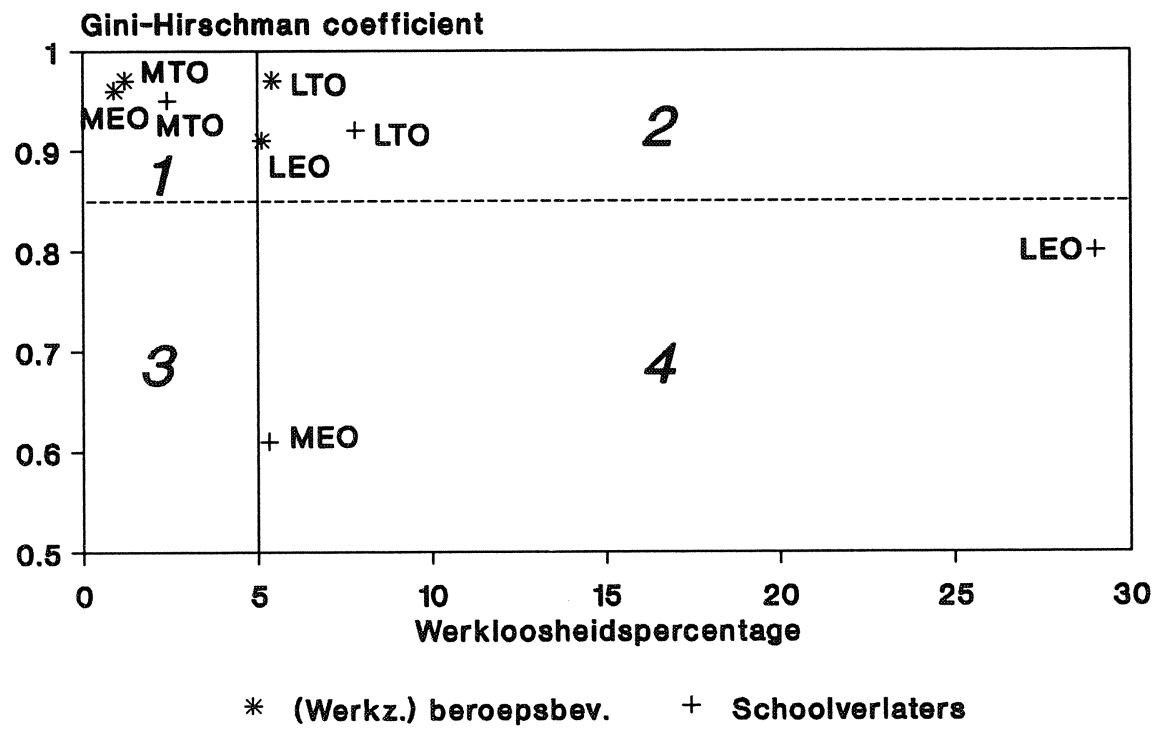

Bron: ROA

$\begin{aligned} \text { LTO } & =\text { LBO Technisch } \\ \text { LEO } & =\text { LBO Economisch-administratief } \\ \text { MTO } & =\text { MBO Technisch } \\ \text { MEO } & =\text { MBO Economisch-administratief }\end{aligned}$

Op basis van de relatie tussen de werkloosheidspercentages en de Gini-Hirschman coëfficiënt kan een uitspraak worden gedaan over de positie van zowel de (werkzame) beroepsbevolking als van schoolverlaters op de arbeidsmarkt. Figuur 4 wordt daarvoor in vier vlakken opgedeeld. De verticale lijn geeft het in deze studie gehanteerde percentage voor de frictiewerkloosheid weer $(5 \%)$. De horizontale lijn in figuur 4 geeft de gemiddelde spreiding over beroepen weer $(0,85)$, gebaseerd op alle werkzame personen over alle opleidingstypen ${ }^{7}$.

Bij een geringe werkloosheid en een hoge spreidingsgraad kan men spreken van een 'structureel' goede arbeidsmarktpositie, omdat de (werkzame) beroepsbevolking en schoolverlaters met de desbetreffende opleidingsachtergrond zowel een grote kans op werk als veel uitwijkmogelijkheden op de arbeidsmarkt hebben (vlak 1). Tot deze categorie behoren de

7. Deze gemiddelde spreiding over beroepen wordt bepaald door het gemiddelde te berekenen van de spreidingscoëfficiënten voor alle opleidingstypen (zie ook ROA, 1992). 
schoolverlaters met een middelbare technische opleiding en de (werkzame) beroepsbevolking die MBO technisch of economisch-administratief heeft afgerond.

Bij een hoog werkloosheidspercentage in combinatie met een hoge spreidingsgraad zou er gesproken kunnen worden van een 'structureel' zwakke arbeidsmarktpositie (vlak 2). Weliswaar bestaan er veel uitwijkmogelijkheden naar andere beroepen, maar desalniettemin slagen relatief weinig personen er in om de concurrentie die men ondervindt vanuit andere opleidingen, te weerstaan. De schoolverlaters uit het lager technisch onderwijs bevinden zich in deze situatie. Met betrekking tot de (werkzame) beroepsbevolking uit het lager technisch en economischadministratief onderwijs is het moeilijk een uitspraak te doen over de 'structurele' arbeidsmarktpositie, omdat de werkloosheidspercentages ongeveer gelijk zijn aan de frictiewerkloosheid.

$\mathrm{Er}$ is eveneens sprake van een 'structureel' zwakke arbeidsmarktpositie bij een hoog werkloosheidspercentage in combinatie met een lage spreidingsindicator (vlak 4). In dit geval zijn namelijk zowel de kans op werk als de uitwijkmogelijkheden klein. Dit geldt met name voor de schoolverlaters uit het lager economisch-administratief onderwijs. Ook de typering van de schoolverlaters uit het middelbaar economisch-administratief onderwijs ligt in dit vlak. Het is echter moeilijk om een uitspraak te doen over de 'structurele' arbeidsmarktpositie, vanwege het werkloosheidspercentage dat ongeveer gelijk is aan de frictiewerkloosheid van $5 \%$. Dit zou er op kunnen duiden dat er voor deze schoolverlaters sprake is van een min of meer evenwichtige situatie op de arbeidsmarkt, omdat deze schoolverlaters niet hoeven uit te wijken naar beroepen buiten hun beroepsdomein.

Doordat de Gini-Hirschman coëfficiënt niet de potentiële maar de gerealiseerde spreiding weergeeft, is het niet goed mogelijk uitspraken te doen over de 'structurele' arbeidsmarktpositie van de opleidingstypen in vlak 3 . Indien wordt verondersteld dat men alleen bij een hoge werkloosheid naar een alternatief beroepsdomein moet uitwijken om een baan te kunnen vinden, kan er ook gesproken worden van een goede arbeidsmarktpositie als zowel het werkloosheidspercentage als de spreidingsindicator laag zijn (vlak 3). In dit geval hebben namelijk vrijwel de hele (werkzame) beroepsbevolking en alle schoolverlaters een baan in hun eigen beroepsdomein kunnen vinden. Het is in dit geval echter onduidelijk of men bij een eventuele daling van de werkgelegenheid in het 'eigen' beroepsdomein in voldoende mate kan uitwijken naar andere beroepsdomeinen, omdat de potentiële uitwijkmogelijkheden niet bekend zijn. Als in een verslechterde situatie de uitwijkmogelijkheden gering blijken te zijn is er mogelijk sprake van een zeker risico. Bovenstaande situatie doet zich bij geen van de onderscheiden groepen voor.

\subsection{Branchespreiding van opleidingen}

Om een indruk te krijgen van de bedrijfssectoren waarin de schoolverlaters en werkzame personen terecht komen wordt, naast de beroepsgroepenspreiding van de opleidingstypen, ook de branchespreiding van de opleidingstypen bepaald met behulp van onderstaande formule, waarbij voor het gekozen aggregatieniveau wordt gecorrigeerd door middel van de correctieterm 
$\frac{J}{J-1}:$

$$
S O B R_{k}=\left(1-\sum_{j=1}^{J} \beta_{k j}^{2}\right) \frac{J}{J-1}
$$

Met: $\operatorname{SOBR}_{k}=$ Gini-Hirschman coëfficiënt branchespreiding van opleiding $\mathrm{k}$

$\beta_{k j} \quad=$ aandeel van bedrijfssector $\mathrm{j}$ in totaal aantal werkenden met opleiding $\mathrm{k}$

$J \quad=$ aantal bedrijfssectoren

In tabel 5 staan de coëfficiënten die een indicatie geven van de spreiding van de opleidingstypen over de verschillende bedrijfssectoren. Opgemerkt moet hierbij worden dat de bovenstaande branchespreiding van de opleidingstypen wordt bepaald voor 21, ook in het ROAinformatiesysteem onderwijs-arbeidsmarkt onderscheiden, bedrijfssectoren.

Tabel 5. Branchespreiding per opleidingstype

$\begin{array}{lll}\text { Opleiding } & \text { Werkzame personen } & \text { Schoolverlaters }\end{array}$

$\begin{array}{llll}\text { LBO } & \text { Technisch } & 0,94 & 0,86 \\ \text { LBO } & \text { Economisch-administratief } & 0,94 & 0,67 \\ & & & 0,88 \\ \text { MBO } & \text { Technisch } & 0,95 & 0,91 \\ \text { MBO } & \text { Economisch-administratief } & 0,92 & 0.92\end{array}$

Bron: ROA

\section{Lager beroepsonderwijs}

Voor beide opleidingstypen uit het lager beroepsonderwijs blijkt dat de spreiding van schoolverlaters over branches lager is dan de desbetreffende spreidingsindicator met betrekking tot het totaal aantal werkzame personen. Dit geldt met name voor het lager economischadministratief onderwijs. Ook de branchespreiding van opleidingen is voor de schoolverlaters nader onderzocht door uit het lager technisch onderwijs enkele belangrijke opleidingsrichtingen te selecteren (zie tabel A3 uit bijlage A). Daarbij moet wel worden opgemerkt dat deze branchespreiding per opleidingsrichting niet, zoals bij de opleidingstypen in tabel $\mathbf{5}$ is gedaan, is bepaald op basis van de spreiding over de diverse bedrijfssectoren, maar op basis van de spreiding over de bedrijfsklassen (2-digitniveau). Voor de richtingen bouwtechniek, consumptieve techniek, textiel verwerking en met name voor installatietechniek is de branchespreiding relatief laag. Voor een drietal richtingen (mechanische techniek, elektrotechniek en motorvoertuigentechniek) blijft de spreiding hoog. 


\section{Middelbaar beroepsonderwijs}

Voor het economisch-administratief onderwijs op MBO-niveau is de branchespreiding voor schoolverlaters vrijwel gelijk aan de branchespreiding van de werkzame personen met de desbetreffende opleidingsachtergrond. Verder valt het op dat de spreidingsgraad van schoolverlaters uit het technisch onderwijs lager is dan voor de totale groep werkzame personen. De branchespreiding voor de schoolverlaters van de drie opleidingsrichtingen die worden onderscheiden binnen het middelbaar economisch-administratief onderwijs vertonen alle drie een relatief hoge spreidingsgraad (zie tabel A3 van bijlage A). Met betrekking tot de schoolverlaters van het middelbaar technisch onderwijs valt op dat de branchespreiding bij de richtingen bouwtechniek, metaal en mode en kleding relatief laag is, terwijl voor elektrotechniek en werktuigbouwkunde de spreiding relatief hoog is. Ook hier moet worden opgemerkt dat de branchespreiding van opleidingsrichtingen is bepaald op basis van de spreiding over bedrijfsklassen (2-digitniveau). 


\section{BESLUIT}

Op basis van eerder ontwikkelde arbeidsmarktindicatoren is in deze studie geprobeerd de arbeidsmarktpositie van opgeleiden uit het technisch en economisch-administratief onderwijs op LBO- en MBO-niveau in beeld te brengen. Daarbij is met name ingegaan op het verschil in arbeidsmarktpositie tussen schoolverlaters aan de ene kant en de gehele beroepsbevolking of de gehele werkzame bevolking aan de andere kant.

De data die in deze studie zijn gebruikt, zijn afkomstig uit een aantal bronnen. Voor gegevens met betrekking tot de kans op werk is gebruik gemaakt van het zogenaamde BZB-bestand van 1990. De overige indicatoren voor de werkzame personen en de schoolverlaters zijn respectievelijk op basis van de EBB 1990 en de RUBS-schoolverlatersenquête 1989 berekend. Er moet echter vanwege de kleine steekproefgrootte in de RUBS-data ten aanzien van de onderscheiden opleidingstypen een voorbehoud worden gemaakt bij de interpretatie van de vergelijking van de arbeidsmarktsituatie van de schoolverlaters met die van de gehele (werkzame) beroepsbevolking. Het rapport heeft derhalve vooral als doel een eerste indruk te geven van de mogelijkheden die een combinatie van de RUBS-schoolverlatersenquête met de EBB-gegevens in de nabije toekomst zou kunnen bieden.

Vaak wordt in aansluitingsonderzoek de arbeidsmarktpositie van schoolverlaters getypeerd aan de hand van slechts een enkel kengetal, zoals het werkloosheidspercentage of de werkloosheidsduur. Voor een evenwichtige beschouwing van de arbeidsmarktpositie is het evenwel van belang om meerdere kernindicatoren te hanteren, die de verschillende aspecten van de aansluiting tussen onderwijs en arbeidsmarkt in beeld brengen. Om een indicatie te geven van de kans op werk en de werkzekerheid zijn in deze studie respectievelijk het werkloosheidspercentage en de conjunctuurgevoeligheid van de werkgelegenheid bepaald. Met betrekking tot het niveau van het werk en de aansluiting daarvan bij het niveau de gevolgde opleiding is gekeken naar het gemiddelde functieniveau en de mate waarin sprake is van onderbenutting. De arbeidsmarktflexibiliteit is tenslotte onderzocht door te kijken naar de verschillende uitwijkmogelijkheden op de arbeidsmarkt: de branche- en beroepenspreiding per opleidingstype.

In tabel 6 wordt een overzicht gegeven van de scores van de onderscheiden opleidingstypen voor de verschillend arbeidsmarktindicatoren. De indicatoren zijn gegroepeerd naar de kans op werk, het niveau van het werk en de uitwijkmogelijkheden. Een plusteken geeft een hoge waarde aan voor desbetreffende indicator en een minteken geeft een lage waarde aan. De nul staat voor het gemiddelde of een situatie van evenwicht ${ }^{8}$.

8. Het gemiddelde is bepaald op basis van de uitkomsten voor de desbetreffende indicatoren voor alle door het ROA onderscheiden opleidingstypen (zie ook ROA, 1992). De indeling wordt gebaseerd op het gemiddelde en de standaard deviatie (zie ook Wieling, De Grip en Willems, 1990) 
Tabel 6. Overzicht van scores van individuele indicatoren

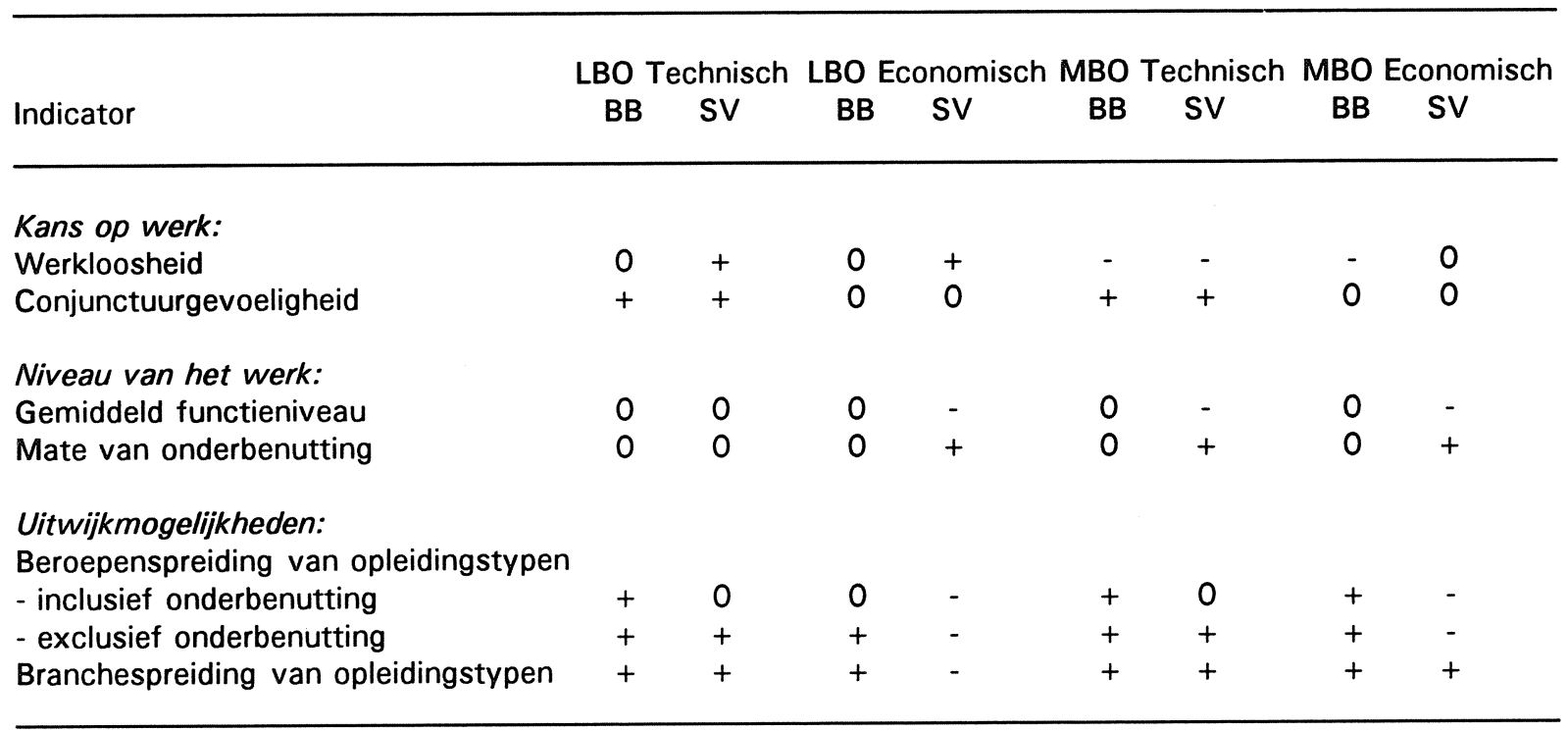

$\mathrm{SV}=$ schoolverlaters

BB = (werkzame) beroepsbevolking

$$
\begin{aligned}
+ & =\text { hoog } \\
0 & =\text { gemiddeld } \\
- & =\text { laag }
\end{aligned}
$$

Bron: ROA

De eerste indicator die is berekend met betrekking tot het vergelijken van de arbeidsmarktpositie van de beroepsbevolking en de schoolverlaters is het werkloosheidspercentage. Voor de onderscheiden opleidingstypen in het lager beroepsonderwijs is er sprake van een ruimere arbeidsmarkt, waarbij schoolverlaters zich duidelijk in een minder gunstige positie bevinden dan de beroepsbevolking. Voor de schoolverlaters uit het middelbaar economisch-administratief onderwijs is de werkloosheid hoger dan voor de beroepsbevolking met deze opleidingsachtergrond. Op basis van de conjunctuurgevoeligheid kan worden geconcludeerd dat de mate waarin de werkgelegenheid voor de werkzame personen en de schoolverlaters in de loop van de tijd aan fluctuaties onderhevig is geweest, niet veel van elkaar verschilt. De conjunctuurgevoeligheid voor het lager en middelbaar technisch onderwijs is voor beide onderzochte groepen relatief erg groot, hetgeen wijst op een instabiele werkgelegenheidssituatie.

Vervolgens is gekeken naar het niveau van het werk. In drie van de geselecteerde opleidingstypen hebben de schoolverlaters gemiddeld een functie van een lager niveau dan de werkzame bevolking, hetgeen samenhangt met het relatief lage niveau van de intredebanen. Opvallend is dat het gemiddelde functieniveau en de mate van onderbenutting voor schoolverlaters uit het lager technisch onderwijs niet minder gunstig is dan voor de werkzame personen. Een mogelijke verklaring hiervoor kan worden gezocht in de veroudering van de scholing van oudere werknemers en de zware fysieke inspanning die technische beroepen vaak vereisen. 
Daarna is ingegaan op de flexibiliteit in de aansluiting tussen opleiding en arbeidsmarkt. Op dit punt wordt er ten onrechte nogal eens van uit gegaan dat er meestal een directe en exclusieve relatie bestaat tussen opleiding en beroep. In de praktijk blijkt echter dat met een bepaalde opleiding doorgaans meerdere beroepen kunnen worden uitgeoefend en dat veel beroepen door mensen met een verschillende opleidingsachtergrond kunnen worden uitgeoefend. Voor de vier geselecteerde opleidingstypen geldt dat de spreiding voor de werkzame personen groter is dan voor de schoolverlaters.

Indien men wil nagaan in hoeverre er sprake is van uitwijkmogelijkheden in positieve zin, moeten beroepen waarin sprake er is van onderbenutting buiten beschouwing worden gelaten. Derhalve is ook de beroepenspreiding van opleidingstypen exclusief de functies waarin sprake is van onderbenutting bepaald. Deze flexibiliteitsindicator laat voor de lagere en middelbare economisch-administratieve opleidingstypen een lagere beroepenspreiding voor schoolverlaters zien dan voor de werkzame personen met deze opleidingsachtergrond.

Juist de combinatie van de besproken indicatoren geeft een goed inzicht in de arbeidsmarktpositie van de verschillende opleidingen. Derhalve zijn enkele van de afzonderlijke indicatoren met elkaar in verband gebracht en is op basis daarvan geprobeerd een typering van de arbeidsmarktpositie te geven.

De combinatie van werkloosheids- en onderbenuttingsgegevens zou men kunnen beschouwen als een indicatie voor de actuele aans/uitingsproblematiek in zowel kwantitatief als kwalitatief opzicht. Er is sprake van een slechte actuele arbeidsmarktpositie, indien het werkloosheidspercentage hoog is in combinatie met een hoge mate van onderbenutting. In dat geval is de kans op werk gering en als men werk heeft kunnen vinden, gaat het veelal om functies op een relatief laag niveau. Bij een geringe werkloosheid en een lage mate van onderbenutting kan daarentegen worden gesproken van een goede actuele arbeidsmarktpositie van de opleiding. In deze situatie is de kans op werk groot en bovendien betreft het hier werk op een aansluitend niveau.

Geen van de onderscheiden groepen wordt gekenmerkt door een zowel in kwantitatief als in kwalitatief opzicht goede aansluiting tussen onderwijs en arbeidsmarkt. Voor de schoolverlaters uit het lager economisch-administratief onderwijs is er sprake van een slechte actuele arbeidsmarktpositie. De hoge werkloosheidspercentages en de hoge percentages onderbenutting geven aan dat men moeilijk een baan kan vinden en als men een baan heeft gevonden, het vaak een functie op een relatief laag niveau betreft.

De combinatie van werkloosheids- en flexibiliteitsgegevens geeft meer inzicht in de 'structurele' arbeidsmarktpositie van een bepaald opleidingstype. Het gaat daarbij om de combinatie van de mate waarin men op dit moment succesvol is in het verwerven van werk en de mate waarin men afhankelijk is van de ontwikkelingen op éen segment van de arbeidsmarkt. Bij een hoge beroepenspreiding en een lage werkloosheid is er sprake van een 'structureel' goede arbeidsmarktpositie, omdat in dat geval de kans op werk groot is en er bovendien sprake is van 
veel uitwijkmogelijkheden op de arbeidsmarkt. Dit is het geval bij de schoolverlaters met een middelbare technische opleiding en de (werkzame) beroepsbevolking die een technische of economisch-administratieve opleiding op MBO-niveau hebben afgerond. De schoolverlaters uit het lager economisch-administratief onderwijs worden daarentegen gekenmerkt door een hoog werkloosheidspercentage en een lage beroepenspreiding. Voor deze schoolverlaters is er sprake van een 'structureel' zwakke arbeidsmarktpositie met een lage kans op werk en geringe uitwijkmogelijkheden naar andere beroepen.

Doordat de spreidingsindicator niet de potentiële maar de gerealiseerde flexibiliteit weergeeft, is het niet goed mogelijk uitspraken te doen over de 'structurele' arbeidsmarktpositie van opleidingen die worden gekenmerkt door een lage werkloosheid en een geringe beroepenspreiding. Indien wordt verondersteld dat men alleen bij een hoge werkloosheid naar een alternatief beroepsdomein moet uitwijken, is er ook sprake van een goede arbeidsmarktpositie als zowel de werkloosheid als de beroepenspreiding laag zijn, omdat de kans op werk in dat geval groot is en men bovendien werk heeft gevonden in het eigen beroepsdomein. Als echter bij een verslechterende arbeidsmarktsituatie de uitwijkmogelijkheden ook klein blijken te zijn, is er sprake van een zeker risico. De combinatie van een lage werkloosheid en een geringe beroepenspreiding doet zich overigens bij geen van de onderscheiden groepen voor. Bij een hoog werkloosheidspercentage in combinatie met een hoge beroepenspreiding zou gesproken kunnen worden van een 'structureel' zwakke arbeidsmarktpositie. Weliswaar bestaan er in dit geval uitwijkmogelijkheden naar andere beroepen, maar desalniettemin slagen velen er niet in de concurrentie die men ondervindt vanuit andere opleidingen te weerstaan. Dit is met name het geval bij de schoolverlaters uit het lager technisch onderwijs.

In het algemeen kan worden geconcludeerd dat er kleine verschillen bestaan tussen de arbeidsmarktpositie van schoolverlaters en de gehele (werkzame) beroepsbevolking. Deze verschillen zijn voornamelijk toe te schrijven aan intrede-effecten. De grootste verschillen tussen schoolverlaters en de gehele (werkzame) beroepsbevolking treden op bij het lager economischadministratief onderwijs. Voor de schoolverlaters met deze opleidingsachtergrond is de positie op de arbeidsmarkt minder gunstige dan voor de gehele (werkzame) beroepsbevolking. Ook de schoolverlaters uit het middelbaar economisch-administratief onderwijs hebben een relatief minder gunstige positie op de arbeidsmarkt. Tenslotte kan worden geconstateerd dat de arbeidsmarktpositie voor de schoolverlaters en de gehele (werkzame) beroepsbevolking uit de technische opleidingstypen op lager en middelbaar niveau beter is dan voor de economischadministratieve opleidingstypen. 


\section{LITERATUUR}

Allaart, P.C., R. Kunnen, W.C.M. Praat, H.A. van Stiphout, J.P. Vosse (1991), Trendrapport aanbod van arbeid 1991, OSA-rapport nr. 12, 's-Gravenhage.

Beekman, Th.B.J., A. de Grip (1991), Werkloosheidsindicatoren voor schoolverlaters, ROA-RM1991/1, Maastricht.

Berendsen, H., A. de Grip, M.H. Wieling, E.J.T.A. Willems (1992), Regionale arbeidsmarktinformatie naar opleiding en beroep; een verkenning vanuit het ROA-informatiesysteem onderwijs-arbeidsmarkt, ROA-R-1992/2, Maastricht.

Borghans, L. (1988), Een interpretatie van de Gini-Hirschman coëfficiënt, Interne notitie, ROA, Maastricht.

CPB (1988), Centraal Economisch Plan 1988, 's-Gravenhage.

Detmar, H., B. Dekker (1987), Het werkloosheidscijfer opnieuw beschouwd, Ministerie van Sociale Zaken, Stichting Research voor Beleid, Leiden.

Grip, A. de, J.A.M. Heijke (1988), Arbeidsmarktindicatoren: een inventarisatie, ROA-W-1988/1, Maastricht.

Grip, A. de, J.A.M. Heijke (1989), Het flexibiliteitspotentieel van universitaire studierichtingen, in: Tijdschrift voor arbeidsvraagstukken, jrg. 5, nr.4, blz. 69-81.

Grip, A. de, L.F.M. Groot, J.A.M. Heijke, E.J.T.A. Willems (1990), De aans/uiting tussen beroepen en functies en de relatie met scholings- en mobiliteitsprocessen, OSAwerkdocument W80, 's-Gravenhage.

Grip, A. de, R.K.W. van der Velden, M.H. Wieling (1991), Indicatoren aans/uiting onderwijs arbeidsmarkt: enkele arbeidsmarktindicatoren op basis van de RUBS-data, ROA-R-1991/2, Maastricht.

Hoof, J.J. van, J. Dronkers (1980), Onderwijs en arbeidsmarkt, Sociologische monografieën, Van Loghum Slaterus, Deventer.

Huijgen, F. (1989), De kwalitatieve structuur van de werkgelegenheid in Nederland. Deel III: bevolking in loondienst en functiestructuur in 1977 en 1985, OSA-voorstudie V33, 'sGravenhage.

Paridon, W.C.G.M. van (1987), De arbeidsmarktindicator, in: Management Berichten, deel II: fluctuaties, Rotterdam.

ROA (1992), De arbeidsmarkt naar opleiding en beroep tot 1994, ROA-R-1992/1, Maastricht.

Sheldon, G. (1985), Die berufliche und geographische Flexibilität, Institut für Arbeidsmarkt und Berufsforschung der Bundesanstalt für Arbeit, Beitrage $A B$ 92, Nürnberg.

Warnken, J. (1986), Zur Entwicklung der "internen" Anpassungsfähigkeit der Berufe bis zum Jahre 2000. Projektionen unter den Annahmen der Wachstumsszenarien der PrognosStudie, in: Mitteilungen aus der Arbeidsmarkt- und Berufsforschung, no.1, blz. 119-133.

Wieling, M.H., A. de Grip, E.J.T.A. Willems (1990), Een systematische kwalitatieve typering van arbeidsmarktinformatie, ROA-W-1990/8, Maastricht. 


\section{BIJLAGE A: DE GINI-HIRSCHMAN COËFFICIËNT}

Zoals reeds in hoofdstuk 5 is opgemerkt heeft de Gini-Hirschman coëfficiënt de neiging snel te stijgen indien met een bepaalde opleiding meerdere beroepen kunnen worden uitgeoefend. Bovendien worden de coëfficiënten hoger naarmate het niveau van de beroepen en branches verder is gedesaggregeerd. In dat geval is namelijk het aantal beroepen en branches waarin de opleidingstypen kunnen voorkomen groter. De opgenomen correctieterm corrigeert in onvoldoende mate voor het niveau van aggregatie. In deze bijlage zal hier verder op worden ingegaan. Daartoe worden voor een aantal belangrijke opleidingsrichtingen binnen de vier hier onderscheiden opleidingstypen, de Gini-Hirschman coëfficiënten voor beroepen- en branchespreiding per opleidingsrichting op verschillende aggregatieniveaus uitgerekend.

Deze bijlage concentreert zich op de schoolverlaters uit de RUBS-data, omdat alleen deze gegevensbron de mogelijkheid biedt om de opleiding-, beroepen- en branchegegevens op verschillende aggregatieniveaus te onderzoeken. Per opleidingstype worden een aantal richtingen onderscheiden met een relatief groot aantal schoolverlaters. Met betrekking tot het lager beroepsonderwijs worden acht opleidingsrichtingen onderscheiden. In het middelbaar technische en economisch-administratief onderwijs worden respectievelijk vijf en drie richtingen onderscheiden. Het lager economisch-administratief onderwijs wordt in deze bijlage buiten beschouwing gelaten, omdat de gegevens voor een verdere opsplitsing niet toereikend zijn.

Als met een bepaalde opleiding meerdere beroepen kunnen worden uitgeoefend heeft de waarde van de Gini-Hirschman coëfficiënt de neiging om waarden aan te nemen die rond de 0,75 liggen. Derhalve wordt naast de 'gewone' Gini-Hirschman coëfficiënt een gecorrigeerde GiniHirschman coëfficiënt bepaald. Met deze gecorrigeerde Gini-Hirschman coëfficiënt wordt getracht een zodanige correctie aan te brengen dat de coëfficiënt de waarde 0,5 aanneemt bij een gemiddelde spreiding. Dit zou de interpretatie van de spreidingsindicator vergemakkelijken.

Om de snelle stijging van de Gini-Hirschman coëfficiënt, indien met een bepaalde opleiding meerdere beroepen kunnen worden uitgeoefend, te voorkomen wordt de gecorrigeerde GiniHirschman (GGH) coëfficiënt bepaald, volgens onderstaande formule (Borghans, 1988):

$$
G G H=1-\sqrt{1-G H}
$$

In tabel A1 staan de Gini-Hirschman coëfficiënten die de beroepenspreiding van 15 opleidingsrichtingen inclusief de functieniveaus waarbij sprake is van onderbenutting weergeven. De beroepenspreiding van opleidingsrichtingen worden voor drie aggregatieniveaus weergegeven. Naast de gewone Gini-Hirschman coëfficiënt $(G H)$ staat in de tabel ook de gecorrigeerde GiniHirschman coëfficiënt (GGH) in de tabel.

Uit tabel A1 blijkt dat voor vrijwel alle onderscheiden opleidingsrichtingen de Gini-Hirschman coëfficiënt groter is naarmate het aggregatieniveau lager is. Slechts voor de richtingen 
textielverwerking uit het lager technisch onderwijs en werktuigbouwkunde, metaalbewerking en mode en kleding ${ }^{9}$ uit het middelbaar technisch onderwijs blijft de spreidingsindicator ongeveer even groot. Grote verschillen tussen de aggregatieniveaus treden op in de richtingen elektrotechniek uit het lager en middelbaar technisch onderwijs en de administratieve richting uit het middelbaar economisch-administratief onderwijs. Het verschil tussen de coëfficiënten op 2en 4-digitniveau bedraagt voor deze richtingen meer dan 0,2. Bovendien bedraagt dit verschil voor ongeveer de helft van de hier onderscheiden richtingen meer dan 0,1 . Voor de richtingen uit het technisch onderwijs is het verschil tussen het 2- en 3-digitniveau meestal groter dan het verschil tussen 3- en 4-digitniveau. Voor het middelbaar economisch-administratief onderwijs geldt het omgekeerde. Uit deze verschillen kan worden geconcludeerd dat zoals in hoofdstuk 5 al is opgemerkt de correctieterm niet volledig voor het gekozen aggregatieniveau corrigeert. Naarmate het aggregatieniveau lager wordt, is het aantal beroepen waartoe iemand met een bepaalde opleidingsrichting kan behoren groter en wordt de Gini-Hirschman coëfficiënt eveneens groter.

Tabel A1.

Beroepenspreiding per opleidingsrichting voor schoolverlaters (inclusief beroepen met functieniveaus waarbij sprake is van onderbenutting) voor verschillende aggregatieniveaus

Opleidingsrichting

2-digitniveau

3-digitniveau

4-digitniveau

GH GGH

GH GGH

$\mathrm{GH}$

GGH

LBO Technisch

Bouwtechniek

\section{0,65}

0,41

0,79

0,54

0,83

0,96

0,59

Mechanische techniek

0,68

0,43

0,95

0,77

0,86

0,81

Consumptieve techniek

0,80

0,55

0,75

0,50

0,62

Textielverwerking

0,61

0,37

0,79

0,54

0,81

0,57

Installatietechniek

0,60

0,37

0,78

0,53

0,85

0,61

Motorvoertuigentechniek

0,58

0,35

0,72

0,42

0,73

0,48

0,47

0,74

0,49

MBO Technisch

Bouwtechniek

Elektrotechniek

Werktuigbouwkunde

Metaalbewerking (incl. goud \& zilver)

Mode en kleding

$\begin{array}{llllll}0,73 & 0,48 & 0,84 & 0,60 & 0,88 & 0,66 \\ 0,66 & 0,42 & 0,87 & 0,64 & 0,94 & 0,76 \\ 0,87 & 0,65 & 0,95 & 0,78 & 0,97 & 0,82 \\ 0,85 & 0,62 & 0,86 & 0,62 & 0,86 & 0,63 \\ 0,78 & 0,53 & 0,78 & 0,54 & 0,80 & 0,56\end{array}$

MBO Economisch-administratief

$\begin{array}{lllllll}\text { Administratief } & 0,48 & 0,28 & 0,54 & 0,32 & 0,69 & 0,44 \\ \text { Commercieel } & 0,65 & 0,41 & 0,71 & 0,46 & 0,83 & 0,59 \\ \text { Secretarieel } & 0,63 & 0,39 & 0,64 & 0,40 & 0,70 & 0,45\end{array}$

Bron: ROA

9. Deze richting valt onder het Middelbaar Dienstverlenings- en Gezondheidszorgonderwijs (MDGO). Volgens de SOl-codering wordt de opleidingsrichting mode en kleding echter tot het technisch onderwijs gerekend. Voor nadere gegevens over dit onderwijstype wordt verwezen naar De Grip, Van der Velden en Wieling (1991). 
Met betrekking tot de gecorrigeerde Gini-Hirschman coëfficiënt kan worden opgemerkt, dat de berekende waarde aanmerkelijk lager zijn dan die van de gewone Gini-Hirschman coëfficiënt. Ook hier zijn echter de verschillen tussen de spreidingsindicatoren op onderscheiden aggregatieniveaus aanzienlijk per opleidingsrichting.

Figuur A1. Verdeling van gewone en gecorrigeerde Gini-Hirschman coëfficiënten: beroepenspreiding van opleidingsrichtingen (inclusief beroepen met functieniveaus waarbij sprake is van onderbenutting)

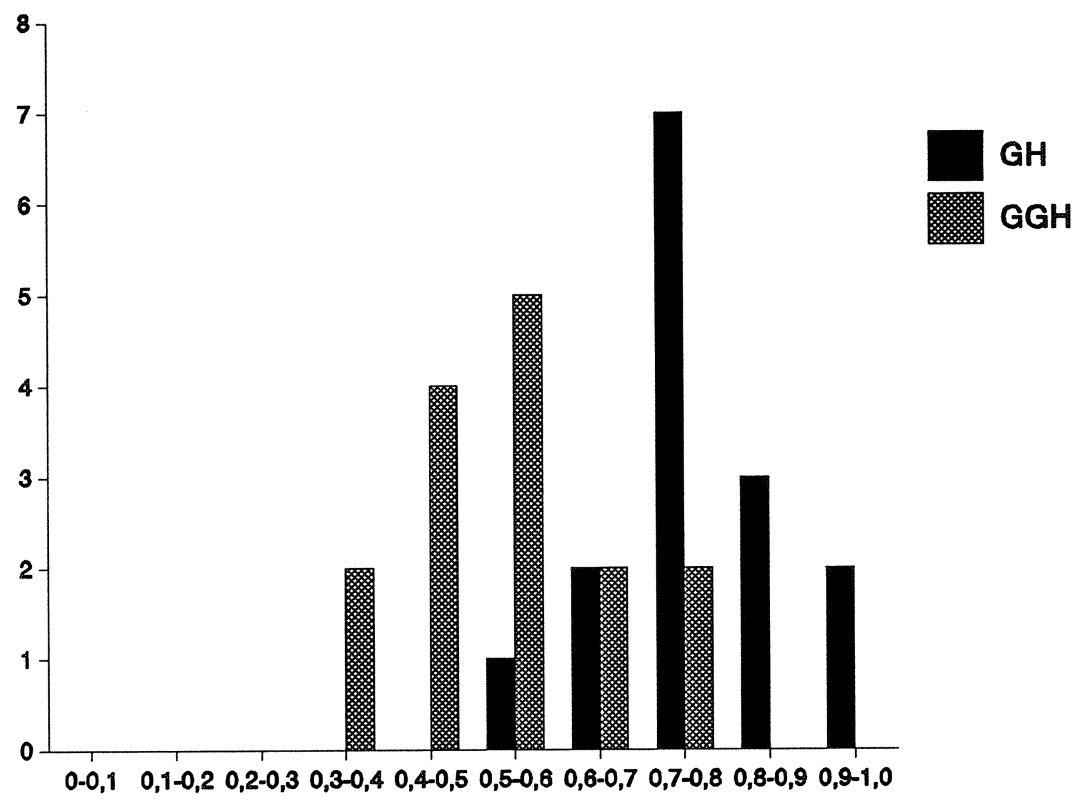

Bron: ROA

In figuur A1 wordt aangegeven hoe vaak de spreidingsindicator die betrekking heeft op de beroepsgroepenspreiding van opleidingsrichtingen inclusief de functies waarbij sprake is van onderbenutting in een bepaald interval voorkomt. Zoals reeds eerder is opgemerkt, blijkt uit de figuur dat de gewone Gini-Hirschman coëfficiënt in het interval 0,7-0,8 is geconcentreerd. Met betrekking tot de gecorrigeerde Gini-Hirschman coëfficiënt liggen echter de meeste waarnemingen liggen in de intervallen $0,4-0,5$ en $0,5-0,6$.

In tabel A2 staan de Gini-Hirschman coëfficiënten die de beroepenspreiding van 15 opleidingsrichtingen exclusief functieniveaus waarbij sprake is van onderbenutting weergeven. De beroepenspreiding van opleidingsrichtingen wordt voor 2 aggregatieniveaus weergegeven. De beroepenspreiding van opleidingsrichtingen op 2-digitniveau kan niet worden bepaald, omdat niet eenduidig is vast te stellen welk functieniveau aan een bepaalde beroepsklasse moet worden toegekend. Naast de gewone Gini-Hirschman coëfficiënt (GH) staat in de tabel ook de gecorrigeerde Gini-Hirschman coëfficiënt (GGH) in de tabel. 
Uit tabel A2 blijkt met betrekking tot de beroepenspreiding van opleidingsrichtingen, exclusief de functieniveaus waarbij er sprake is van onderbenutting, dat eveneens voor vrijwel alle onderscheiden opleidingsrichtingen de Gini-Hirschman coëfficiënt groter is naarmate het aggregatieniveau lager is. Over het algemeen is de het verschil tussen de aggregatieniveaus kleiner dan bij de beroepenspreiding van opleidingsrichtingen, inclusief de functieniveaus waarbij sprake is van onderbenutting. Slechts voor een aantal richtingen uit het lager technisch onderwijs (consumptieve techniek, textielverwerking en elektrotechniek) is het verschil in de spreidingsindicator voor de onderscheiden aggregatieniveaus groter dan 0,1 . Ook in dit geval corrigeert de correctieterm echter niet volledig voor het gekozen aggregatieniveau. Hoewel de verschillen ten opzichte van de beroepenspreiding inclusief de onderbenutting kleiner zijn, geldt ook voor de beroepenspreiding voor aansluitend of hoger niveau dat naarmate het aggregatieniveau lager wordt, het aantal beroepen waartoe iemand met een bepaalde opleidingsrichting kan behoren groter is en de Gini-Hirschman coëfficiënt derhalve groter wordt.

Tabel A2. Beroepenspreiding per opleidingsrichting voor schoolverlaters (exclusief beroepen met functieniveaus waarbij sprake is van onderbenutting) voor verschillende aggregatieniveaus

\section{Opleidingsrichting}

3-digitniveau

$\mathrm{GH} \quad \mathrm{GGH}$ 4-digitniveau

GH GGH

\section{LBO Technisch}

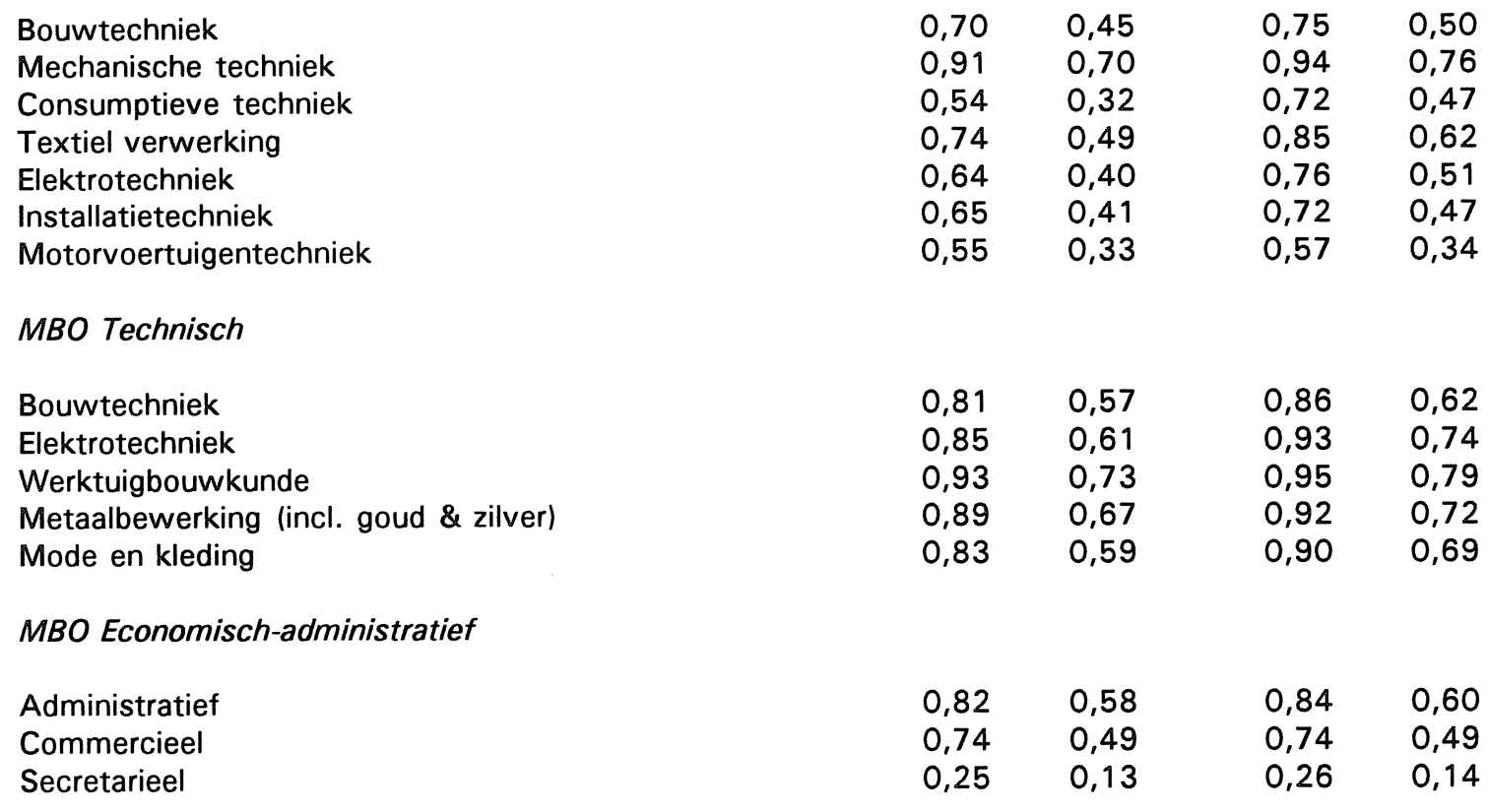

Bron: ROA

Met betrekking tot de gecorrigeerde Gini-Hirschman coëfficiënt kan worden opgemerkt, dat de berekende waarden aanmerkelijk lager zijn dan de gewone Gini-Hirschman coëfficiënt. Het verschil tussen de beroepsgroepenspreiding en de beroepenspreiding van opleidingsrichtingen is voor alle onderscheiden opleidingsrichtingen groter dan 0,1 . 
In figuur A2 wordt aangegeven hoe vaak de spreidingsindicator die betrekking heeft op de beroepsgroepenspreiding van opleidingsrichtingen exclusief de functies waarbij sprake is van onderbenutting in een bepaalde interval voorkomt. Uit figuur A2 blijkt dat de gewone GiniHirschman coëfficiënt in de intervallen $0,6-0,7$ en 0,8-0,9 is geconcentreerd, terwijl voor de gecorrigeerde Gini-Hirschman coëfficiënt de meeste waarden tussen 0,3 en 0,7 liggen.

Figuur A2. Verdeling van gewone en gecorrigeerde Gini-Hirschman coëfficiënten: beroepenspreiding van opleidingsrichtingen (exclusief beroepen met functieniveaus waarbij sprake is van onderbenutting)

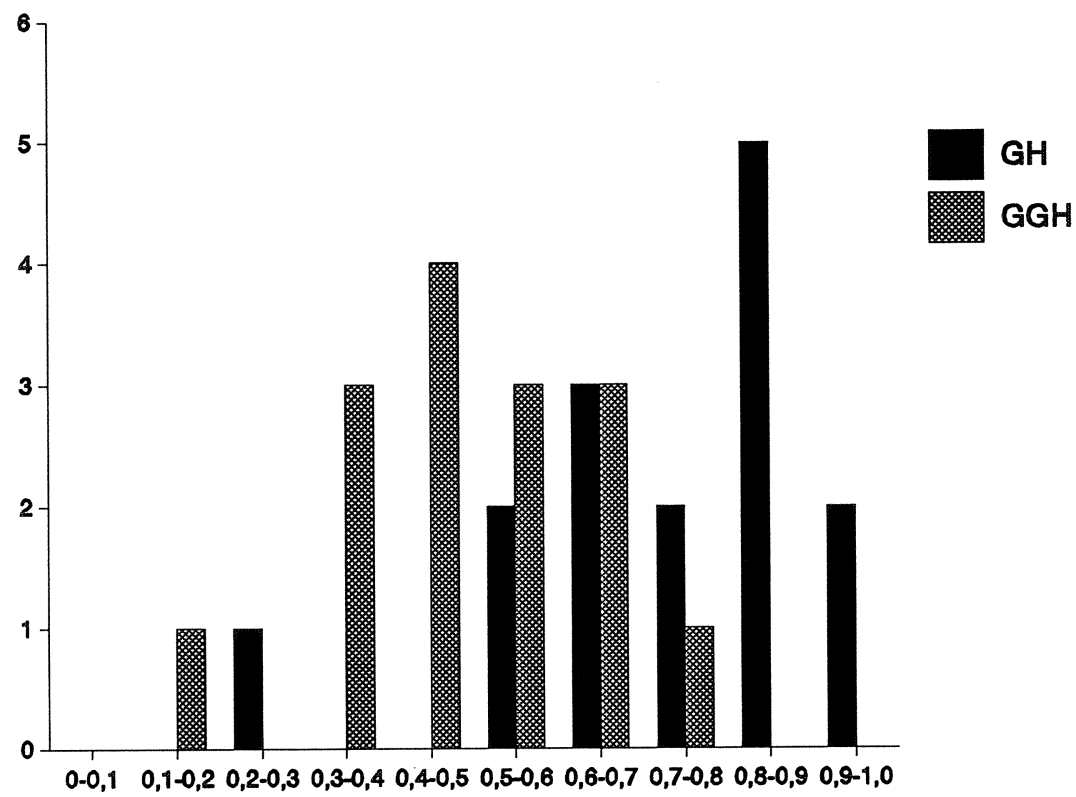

Bron: ROA

Tabel A3 geeft een overzicht van de Gini-Hirschman coëfficiënten die de branchespreiding van 15 opleidingsrichtingen weergeven. De branchespreiding van opleidingsrichtingen worden voor drie aggregatieniveaus weergegeven. Ook voor deze spreidingsindicator wordt naast de gewone Gini-Hirschman coëfficiënt (GH) ook de gecorrigeerde Gini-Hirschman coëfficiënt (GGH) in de tabel gepresenteerd.

Uit tabel A3 blijkt dat voor de branchespreiding van opleidingsrichtingen de relatie van de GiniHirschman coëfficiënt met het aggregatieniveau grilliger is dan bij de beroepenspreiding van opleidingsrichtingen. Met uitzondering van de commerciële richting uit het middelbaar economisch-administratief onderwijs is de Gini-Hirschman coëfficiënt voor het 4-digitniveau groter dan voor het 2-digitniveau. Voor de opleidingsrichtingen uit het middelbaar economischadministratief onderwijs is de spreidingsindicator met branche op 3-digitniveau groter dan op 4digitniveau. Voor twee richtingen uit het lager technisch onderwijs (elektrotechniek en motorvoertuigentechniek) is de spreidingsindicator naar bedrijfsklasse groter dan naar 
bedrijfsgroep. Voor bouwtechniek, consumptieve techniek, textielverwerking en installatietechniek uit het lager technisch onderwijs is het verschil tussen de aggregatieniveaus vrij groot. Evenzo bedraagt het verschil voor de richting mode en kleding uit het middelbaar technisch onderwijs bijna 0,2 .

Tabel A3. Branchespreiding per opleidingsrichting voor schoolverlaters voor verschillende aggregatieniveaus

\begin{tabular}{|c|c|c|c|}
\hline Opleidingsrichting & 2-digitniveau & 3-digitniveau & 4-digitniveau \\
\hline & $\mathrm{GH} \quad \mathrm{GGH}$ & $\mathrm{GH} \quad \mathrm{GGH}$ & $\mathrm{GH} \quad \mathrm{GGH}$ \\
\hline
\end{tabular}

LBO Technisch

$\begin{array}{lllllll}\text { Bouwtechniek } & 0,53 & 0,31 & 0,75 & 0,50 & 0,78 & 0,53 \\ \text { Mechanische techniek } & 0,91 & 0,71 & 0,94 & 0,75 & 0,96 & 0,80 \\ \text { Consumptieve techniek } & 0,65 & 0,41 & 0,70 & 0,45 & 0,83 & 0,58 \\ \text { Textiel verwerking } & 0,68 & 0,43 & 0,87 & 0,64 & 0,91 & 0,71 \\ \text { Elektrotechniek } & 0,86 & 0,63 & 0,85 & 0,62 & 0,95 & 0,78 \\ \text { Installatietechniek } & 0,28 & 0,15 & 0,68 & 0,43 & 0,57 & 0,35 \\ \text { Motorvoertuigentechniek } & 0,80 & 0,55 & 0,78 & 0,53 & 0,82 & 0,57\end{array}$

MBO Technisch

$\begin{array}{lllllll}\text { Bouwtechniek } & 0,65 & 0,41 & 0,67 & 0,42 & 0,70 & 0,45 \\ \text { Elektrotechniek } & 0,91 & 0,70 & 0,92 & 0,72 & 0,97 & 0,82 \\ \text { Werktuigbouwkunde } & 0,94 & 0,75 & 0,97 & 0,83 & 0,97 & 0,83 \\ \text { Metaalbewerking (incl. goud \& zilver) } & 0,69 & 0,44 & 0,77 & 0,52 & 0,70 & 0,45 \\ \text { Mode en kleding } & 0,68 & 0,44 & 0,89 & 0,67 & 0,88 & 0,66\end{array}$

MBO Economisch-administratief

$\begin{array}{lllllll}\text { Administratief } & 0,93 & 0,73 & 0,95 & 0,77 & 0,93 & 0,74 \\ \text { Commercieel } & 0,90 & 0,68 & 0,90 & 0,69 & 0,86 & 0,62 \\ \text { Secretarieel } & 0,94 & 0,76 & 0,97 & 0,84 & 0,96 & 0,80\end{array}$

Bron: ROA

Met betrekking tot de gecorrigeerde Gini-Hirschman coëfficiënt kan worden opgemerkt, dat de berekende waarden aanmerkelijk lager zijn dan de gewone Gini-Hirschman coëfficiënt. Ook hier zijn echter de verschillen tussen de spreidingsindicatoren op de onderscheiden aggregatieniveaus aanzienlijk, met name bij het lager technisch onderwijs. 


\section{BIJLAGE B: DE BELANGRIJKSTE BEROEPEN PER OPLEIDINGSTYPE}

Tabel B1. Belangrijkste beroepsgroepen waarin werkzame personen en schoolverlaters werkzaam zijn

Code Beroepsgroep Werkzame personen Schoolverlaters

LBO Technisch

331 Boekhouder, bedrijfsadministrateur

Postsorteerder, postbesteller $\quad x$

Employé goederenexpeditie e.d. $\quad x$

Administratief personeel

Winkelbediende, verkoper

$\mathbf{x}$

Kok en overig keukenpersoneel

Kelner, serveerster, barkeeper e.d.

$x$

552

641

701

702

773

776

833

841

843

845

851

855

871

872

873

874

931

951

954

958

959

971

Schoonmaakpersoneel, glazenwasser

Visser

Leidinggevend personeel industriële produktie

Leidinggevend personeel bouw, elektriciteitsproduktie

Slachter, slager

Bakker, suikerwerkmaker e.d.

Machinale metaalbewerker e.d.

Machinebankwerker, machinemonteur

Automonteur, rijwielhersteller e.d.

Machine-, onderhoudsmonteur

Elektrotechnisch bankwerker e.d.

Elektricien

Loodgieter, pijpfitter e.d.

Lasser, brander, snijder e.d.

Plaatwerker e.d.

Constructie (plaat/bank)werker

Huisschilder, scheepsschilder e.d

Metselaar, tegelzetter e.d.

Timmerman e.d.

Aannemer (kleinbedrijf) e.d.

Behanger, sloper van gebouwen e.d.

Lader, losser, magazijnbediende e.d.

$\mathrm{x}=$ meer dan $1 \%$ van de werkzame personen is werkzaam in deze beroepsgroep

Bron: ROA 
$-38-$

Tabel B2. Belangrijkste beroepsgroepen waarin werkzame personen en schoolverlaters werkzaam zijn

Code Beroepsgroep Werkzame personen Schoolverlaters

\section{$\angle B O$ Economisch-administratief}

072 Leerling-verpleegkundige, ziekenverzorger $\quad x$

321 Secretaresse, typist, telexist $\quad x \quad x$

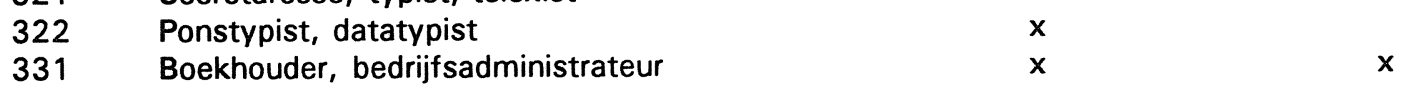

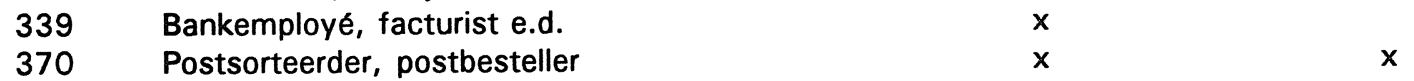

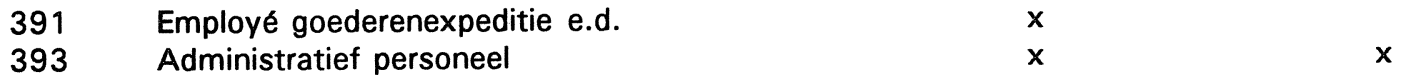

394 Receptionist, informatrice VVV e.d.

462 Vertegenwoordiger, handelsagent

481 Winkelbediende, verkoper
482 Straat-, markt- en krantenverkoper

532 Kelner, serveerster, barkeeper e.d.

542 Verzorgend personeel n.e.g.

552 Schoonmaakpersoneel, glazenwasser

570 Kapper, schoonheidsspecialiste

622 Tuinder e.d.

773 Slachter, slager

971 Lader, losser, magazijnbediende e.d.

$\mathbf{x}=$ meer dan $1 \%$ van de werkzame personen is werkzaam in deze beroepsgroep 
$-39-$

Tabel B3. Belangrijkste beroepsgroepen waarin werkzame personen en schoolverlaters werkzaam zijn

\begin{tabular}{lll}
\hline Code Beroepsgroep & Werkzame personen & Schoolverlaters \\
\hline
\end{tabular}

\section{MBO Technisch}

014 Analist, laborant, assistent e.d.

028 Bedrijfskundige, arbeidsanalist

032 Tekenaars

033 Bouwkundig technicus (midden niveau)

034 Elektronicus (midden niveau)

035 Werktuig(bouw)kundige (midden niveau)

054 Biologisch laborant e.d.

Reclame-ontwerper, etaleur e.d.

Directeur N.V., overheidsbedrijf

Zelfstandig bedrijfshoofd

Secretaresse, typist, telexist

Boekhouder, bedrijfsadministrateur

Administratief personeel

Verkoopchef, filiaalhouder

Winkelbediende, verkoper

Kelner, serveerster, barkeeper e.d.

Leidinggevend personeel industriële produktie

Leidinggevend personeel bouw, elektriciteitsproduktie

Bakker, suikerwerkmaker e.d.

Kleermaker, coupeur

Confectienaaister, -stikker

Machinale metaalbewerker e.d.

Machinebankwerker, machinemonteur

Klokken-, horlogemaker e.d.

Automonteur, rijwielhersteller e.d.

Machine-, onderhoudsmonteur

Elektrotechnisch bankwerker e.d.

Elektronicamonteur

Elektricien

Telefoonmonteur, -installateur

Loodgieter, pijpfitter e.d.

871

Constructie (plaat/bank)werker

Goud- en zilversmid e.d.

$\begin{array}{ll}x & x \\ x & x \\ x & x \\ x & \end{array}$

$x=$ meer dan $1 \%$ van de werkzame personen is werkzaam in deze beroepsgroep 
$-40-$

Tabel B4. Belangrijkste beroepsgroepen waarin werkzame personen en schoolverlaters werkzaam zijn

\begin{tabular}{lll}
\hline Code Beroepsgroep & Werkzame personen & Schoolverlaters
\end{tabular}

\section{MBO Economisch-administratief}

084 Programmeur e.a. computerdeskundigen $\quad x$

211 Directeur N.V., overheidsbedrijf $x$

219 Hogere leidinggevende functie $\quad x$

321 Secretaresse, typist, telexist $x$

331 Boekhouder, bedrijfsadministrateur

339 Bankemployé, facturist e.d.

380 Telefoniste, telegrafist e.d.

391 Employé goederenexpeditie e.d.

393 Administratief personeel

394 Receptionist, informatrice VVV e.d.

412 Bedrijfsleider detailhandel

421 Zelfstandig groothandelaar, importeur

431 Zelfstandig winkelier in levensmiddelen

Verkoopchef, filiaalhouder Inkoper

Vertegenwoordiger, handelsagent

Verzekeringsagent, makelaar e.d.

Winkelbediende, verkoper

Lader, losser, magazijnbediende e.d.

$x=$ meer dan $1 \%$ van de werkzame personen is werkzaam in deze beroepsgroep 